\title{
Development and evaluation of model of implementation barriers, disclosure and standardization of corporate sustainability in Iran
}

\author{
Darioush Akhtarshenas \\ Ph. D in Accounting, Lecturer of Accounting Department of Razi University, \\ Kermanshah,Iran(Darioushakhtarshenas89@gmail.com) \\ Ahmad Khodamipour* \\ Associate Professor of Accounting, Shahid Bahonar University of Kerman, \\ Kerman,Iran(Corresponding Author),Khodamipour@uk.ac.ir \\ Omid Pourheidari \\ Professor of Accounting, Shahid Bahonar University of Kerman, Kerman, \\ Iran(Opourheidari@uk.ac.ir)
}

\begin{abstract}
:
Corporate sustainability plays a key role in integrating and pursuing the economic, social and environmental goals of companies. The purpose of this study is the development and evaluation of model of implementation barriers, disclosure and standardization of corporate sustainability in Iran. In this study, with the help of interviews with 20 experts by using a snowball sampling method based on the thematic analysis of the interviews, the research model has been developed. Also, in order to assess the validity of the presented model, using a researcher-made questionnaire whose validity and reliability were confirmed, the opinions of 123 experts were received in 2019 and analyzed. Research findings indicate that, lack of coherent legal requirements, weak infrastructure in the field of education, technology and human resources, and underdeveloped accountability and accountability system and lack of demands of the society are the most important of implementation barriers corporate sustainability. From the perspective of this study, non-mandatory sustainability reporting, the lack of a standard for sustainability reporting and the lack of a model and the difficulty of measuring corporate sustainability are the most important of barriers to disclosing corporate sustainability. The findings also، showed that the quality of corporate sustainability and the difficulty of formulating the standard for it are the most important of barrier to formulating the standard for corporate sustainability. Accordingly, it is suggested to government and companies to provide the infrastructure,
\end{abstract}

Copyrights:

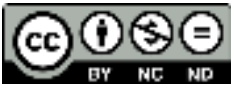

This license only allowing others to download your works and share them with others as long as they credit you, but they can't change them in any way or use them commercial. 
capacity and facilities needed to implement corporate sustainability. It is also suggested to Corporate Audit and the Securities Exchange Organization to take the necessary steps for codification corporate sustainability laws and standard.

Keywords: Corporate sustainability, Thematic Analysis, Environmental, Sustainability reporting.

\section{Copyrights:}

\section{(c) $(1)(3) \Theta$}

This license only allowing others to download your works and share them with others as long as they credit you, but they can't change them in any way or use them commercial. 


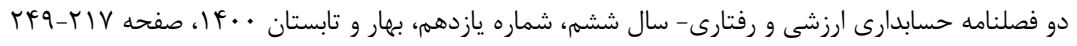

\section{تدوين و ارزيابى مدل موانع اجرا، افشا و استانداردكذارى بايدارى

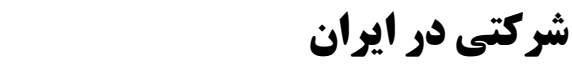

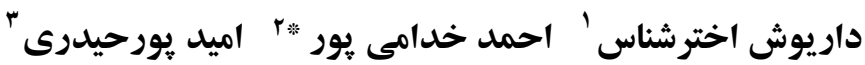

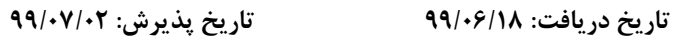

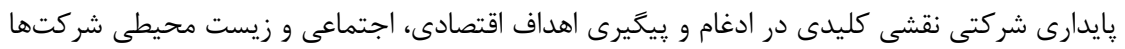

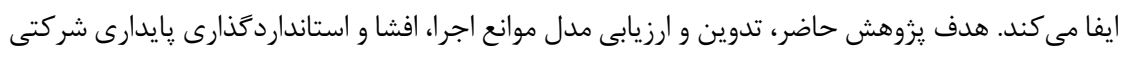

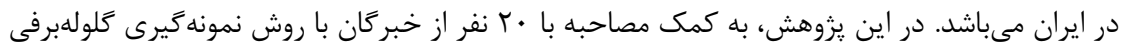

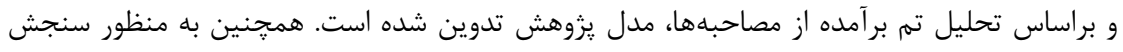

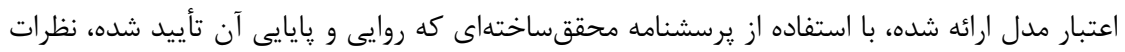

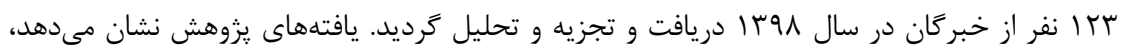

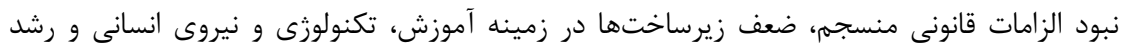

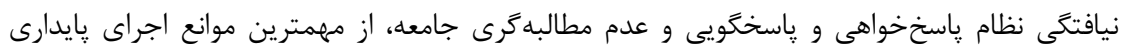

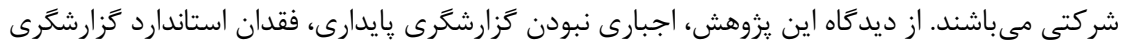

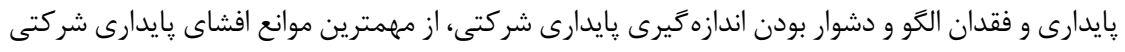

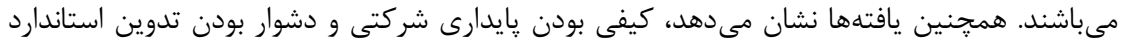

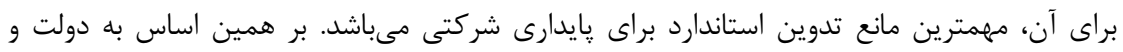

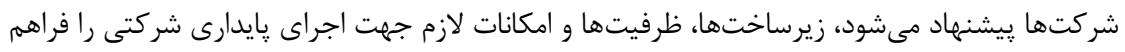

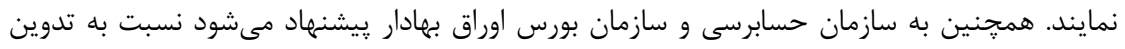

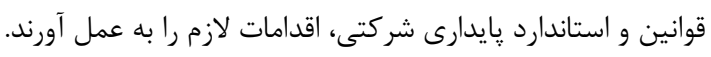

وازه هاى كليدى: يايدارى شركتى، تحليل تم، زيستمحيطى، گَارشكَى يايدارى.

$$
\text { 'دكترى حسابدارى، مدرس گروه حسابدارى دانشگاه رازى، كرمانشاه، ايران }
$$

(Darioushakhtarshenas89@gmail.com)

$$
\text { 'دانشيار گروه حسابدارى دانشعاه شهيد باهنر كرمان، كرمان، ايران (نويسندهى مسئول)، }
$$

Khodamipour@uk.ac.ir "استاد گروه حسابدارى دانشعاه شهيد باهنر كرمان، كرمان، ايران(Opourheidari@uk.ac.ir) 
ב

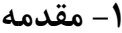

يكى از نخستين و شناختهشدهرين تعريفهاى يايدارى شركتى كه توسط كميسيون جهانى

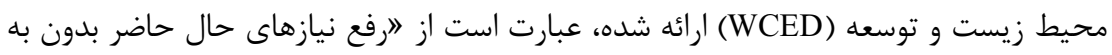

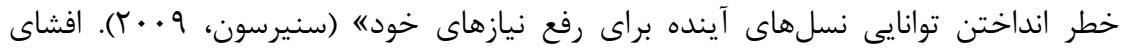
يايدارى شركتى به عنوان ابزارى براى مديريت شرايط زيست محيطى و اجتماعى، ياسخى به

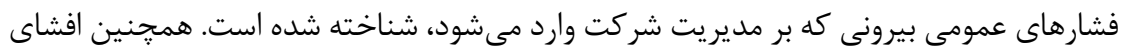
يايدارى شركتى ابزارى براى شركتهاست تا عملكرد اقتصادى، اجتماعى و زيست محيطى خود را به گروههاى ذينفع گزارش داده و بدين وسيله عدم تقارن اطلاعاتى را كاهش دهند (زانگ،

كاهش تنوع جانوران و گياهان، آلودگى آب و هوا و گرم شدن زمين از جمله يِامدهاى بالا بردن سود شركتها، بدون توجه به محيط اطراف آنها است. يزوهشگران بر اين باورند كه

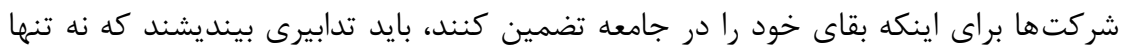
منافع سهامداران، بلكه منافع ديخر ذىنفعان مانند كاركنان، تأمين كنند اتحاديهها، مقامهاى نظارتى و سازمانهاى غيردولتى را نيز در نظر بخيرند (يارمر و همكاران،

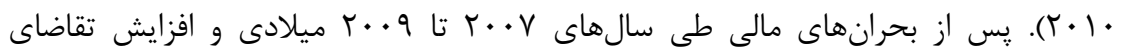

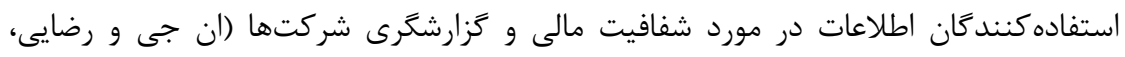
ها • r)، اطلاعات مالى و غيرمالى شفاف، دقيق و قابل اعتماد، از طريق گزارشگرى يايدارى

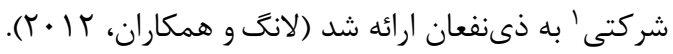
تغيير در انتظارات جامعه از بنگاههاى اقتصادى منجر به ايجاد تعاريف جديد و ويدايش يديدههايى همجون توسعه يايدار و پايدارى شركتى شده است. توسعه يايدار مفهومى است كه

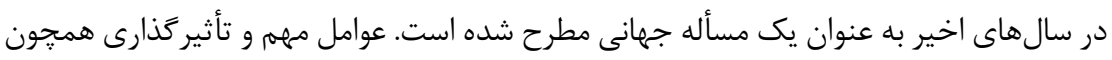
بحران مالى و رسوايىهاى مالى شركتهاى بزرى جهان سبب شد كه نيازهاى اطلاعاتى استفاده كنندگان افزايش يابد و مديريت فراتر از تعهدات قانونى خود به صورت داوطلبانه

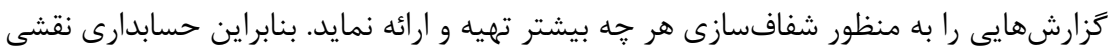

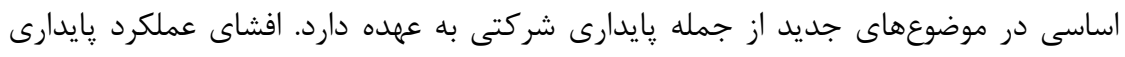
شركتى انگيزه زيادى براى شركتها جهت بهبود مزيت رقابتى خود، ايجاد كرده است (كارسيا و

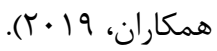

1. Corporate Sustainability 
دكتر خدامى يور و همكاران، تدوين و ارزيابى مدل موانع اجرا، افشا و استانداردَّذارى يايدارى شركتى در ايران M

اگر جه رويه هاى گزارشكرى مالى از طريق استانداردهاى حسابدارى شكل قانونى مى

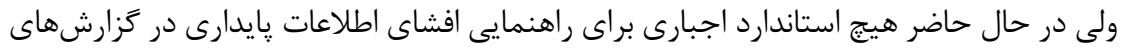

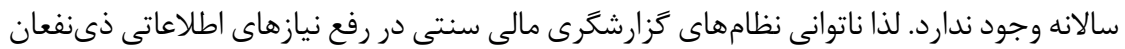

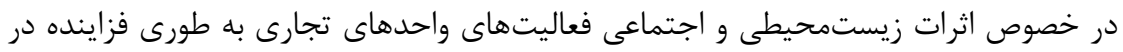

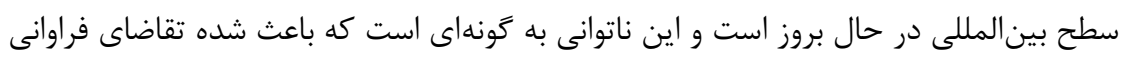

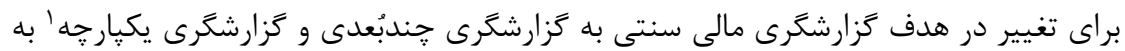

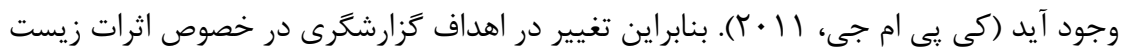

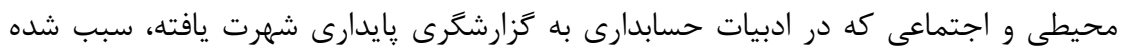

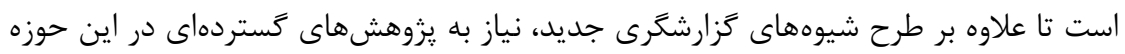

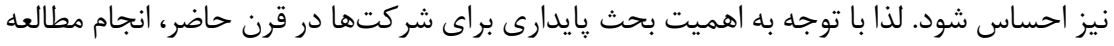

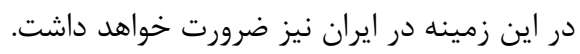

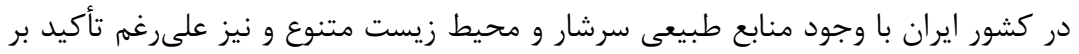

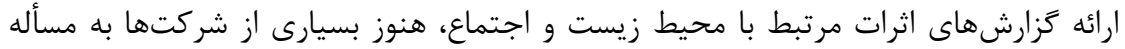

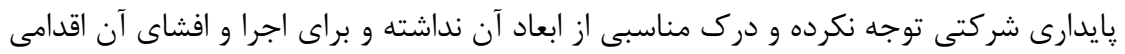

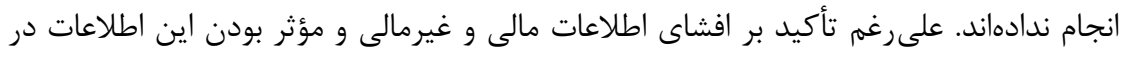

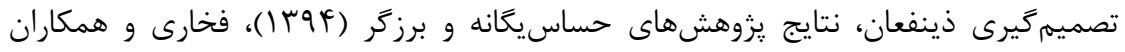

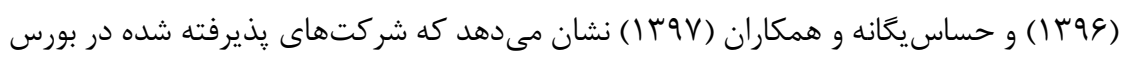

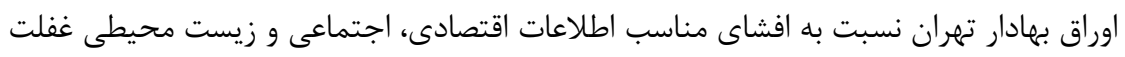

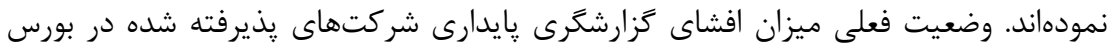

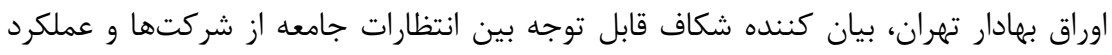

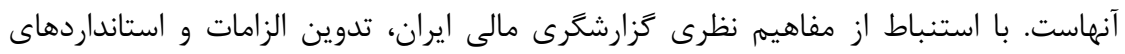

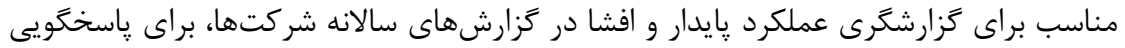

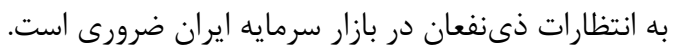

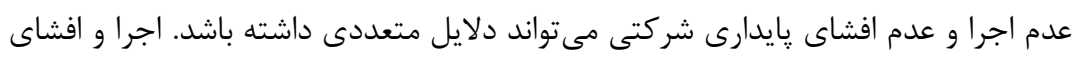

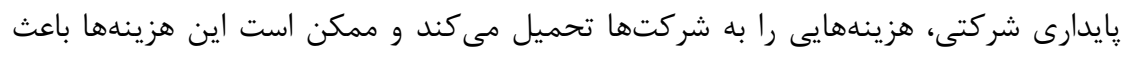

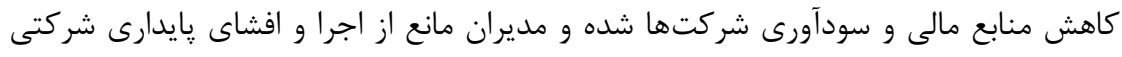

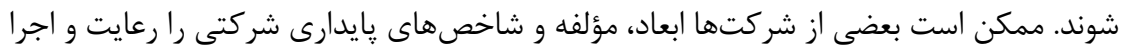

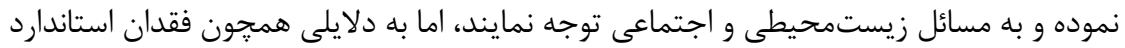

${ }^{1}$. Integrated Reporting 
و ضعف زيرساختها، قادر به افشاى آن در تزارشهاى مالى نباشند. همجنين ممكن است بعضى

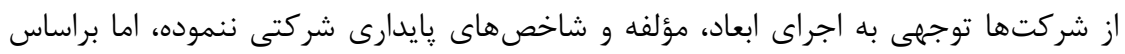

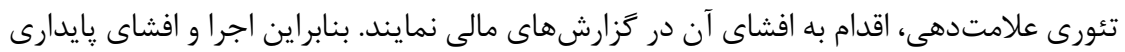

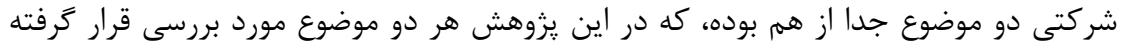

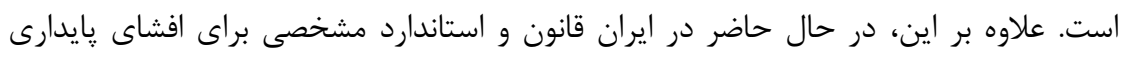

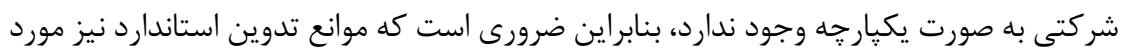
بررسى قرار گيرد.

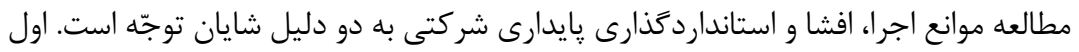

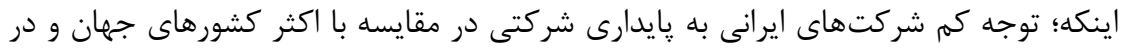
معرض ابهام قرار گرفتن تدوام فعاليت بلندمدت اين شركتها، بسيار مشهود است. دوم اينكه؛

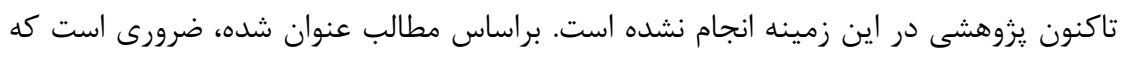

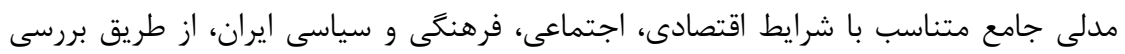

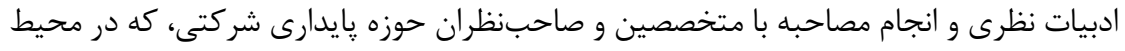

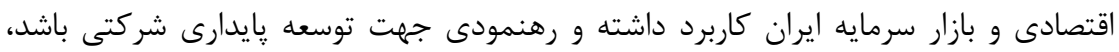

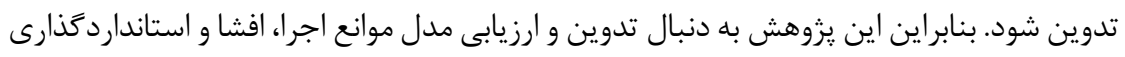

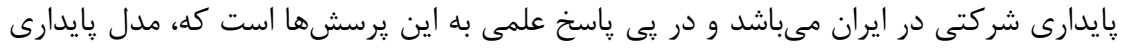

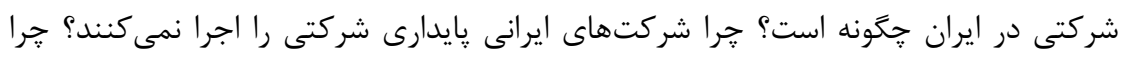

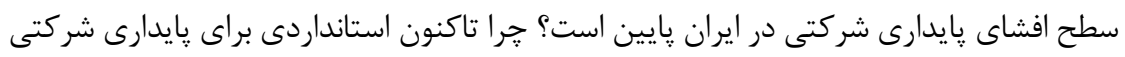

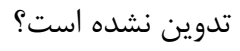

\section{r- مبانى نظرى و ييشينه يزوهش}

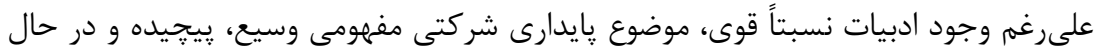

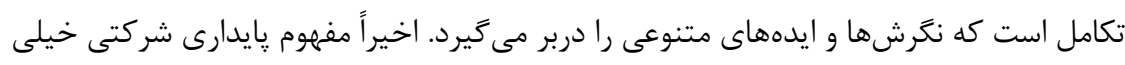

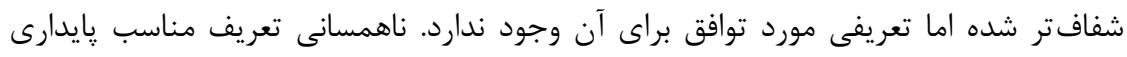

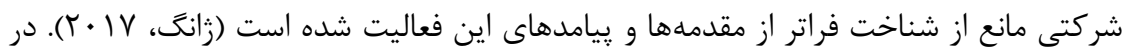

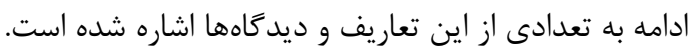

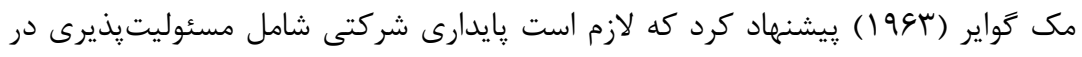

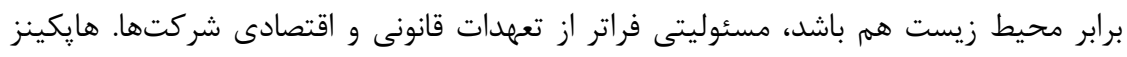

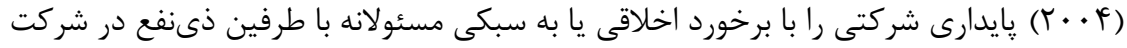

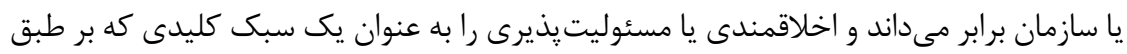




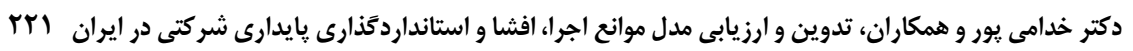

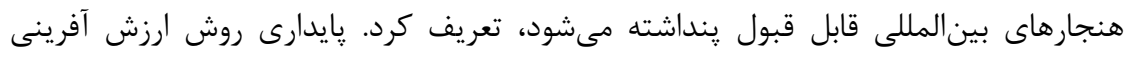

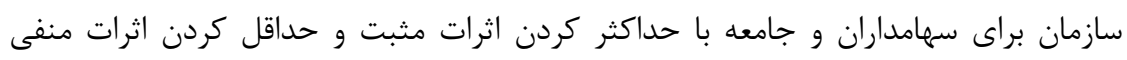

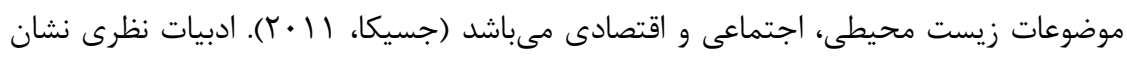

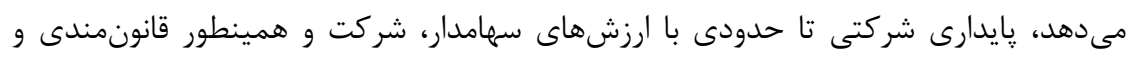

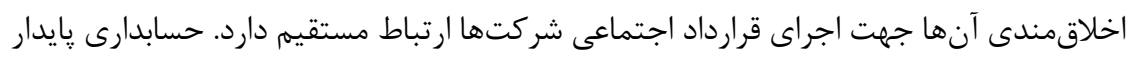

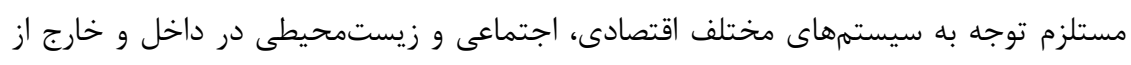

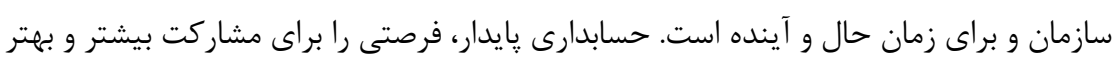

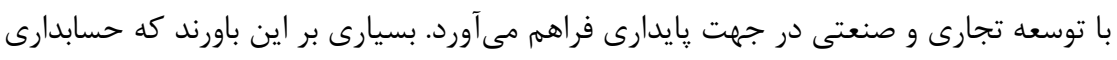

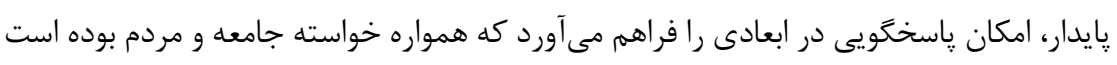

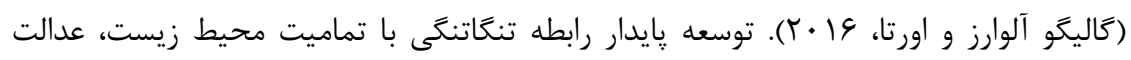

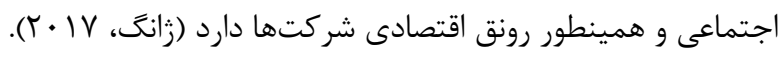

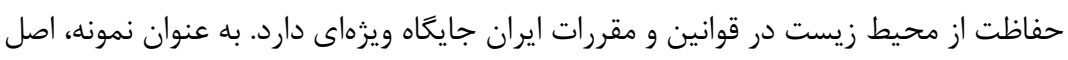

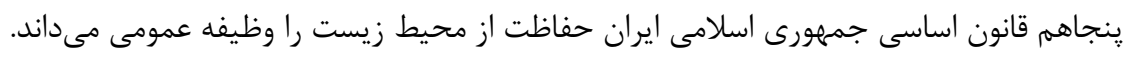

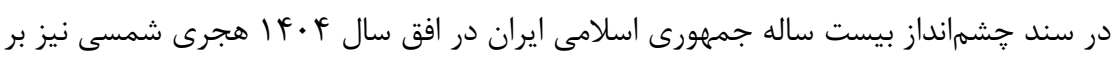

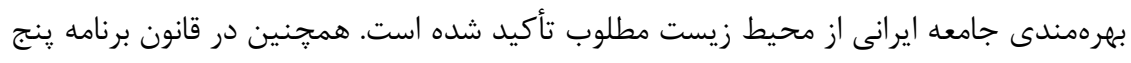

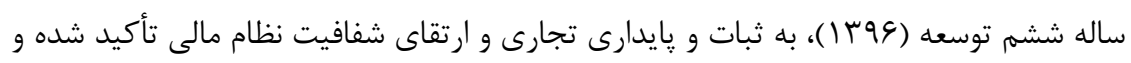

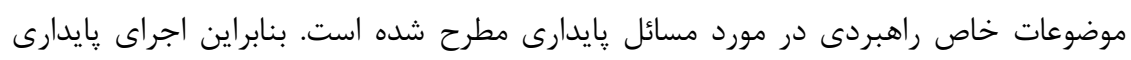
شركتى براى شركتها امرى لازم و ضرو ضروى مورد است.

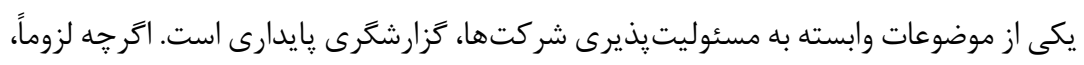

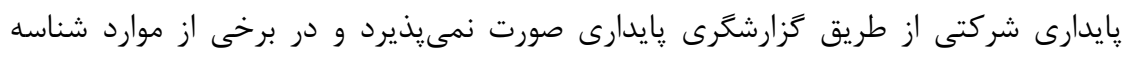

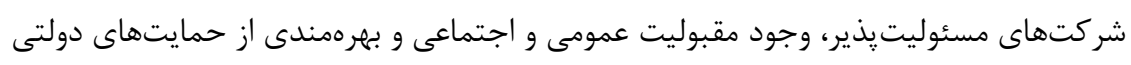

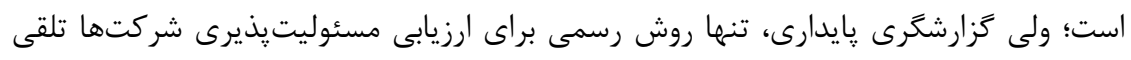

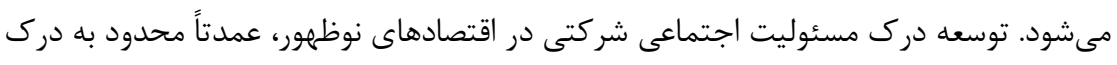

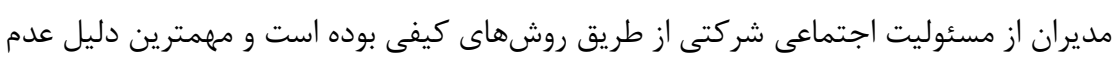

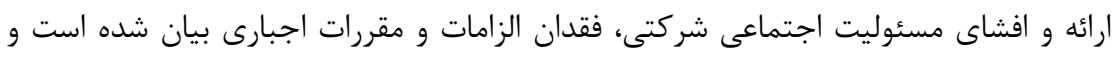

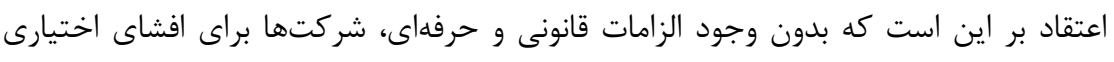

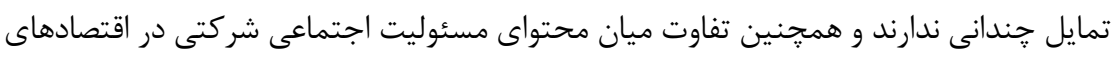

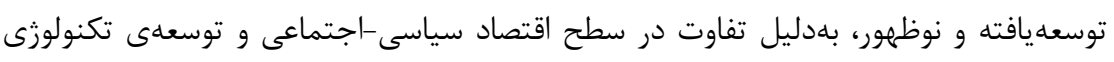

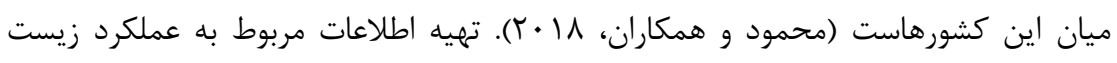

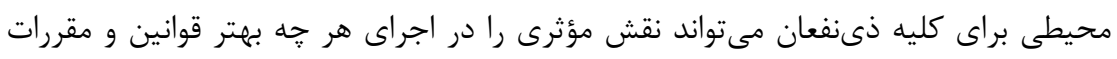


موجود در حوزه محيط زيست ايفا كند. براساس ماده سب آييننامه اصول راهبرى شركتهاى

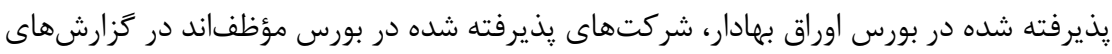
سالانه خود اطلاعات كلى در مورد مسئوليتهاى اجتماعى و زيست محيطى ارئه ائه كنند.

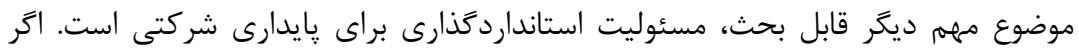

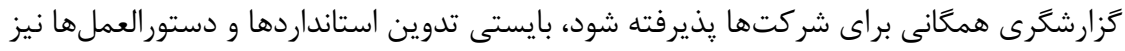

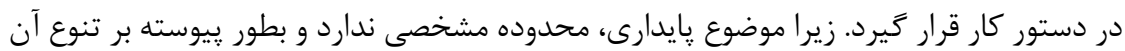

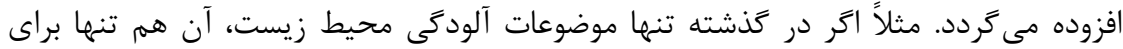

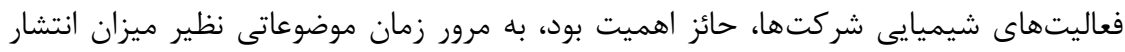

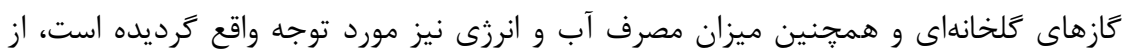

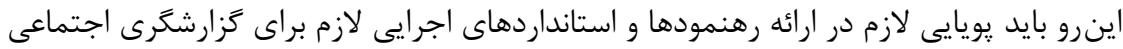
و و محيطى وجود داشته باشد.

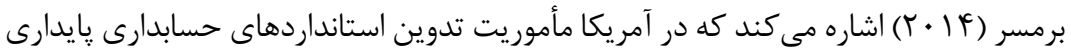

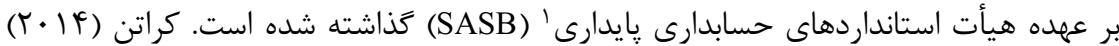

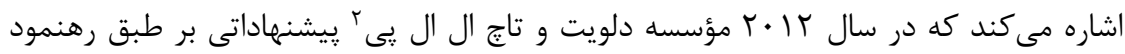

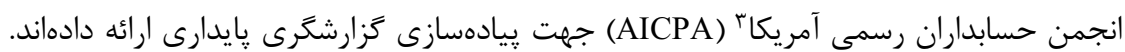

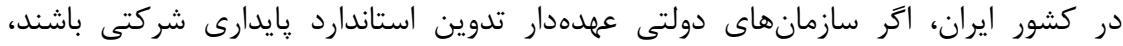

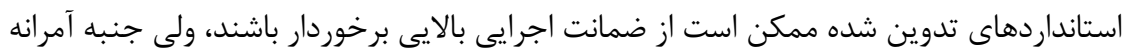

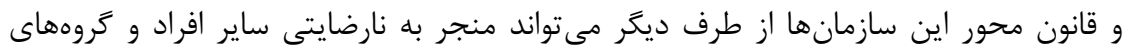

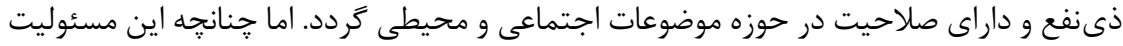

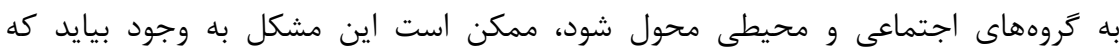

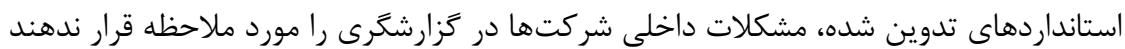

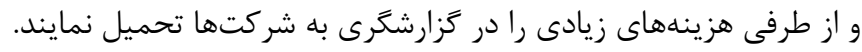

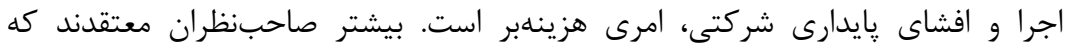

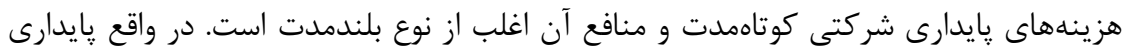
شركتى نوعى سرمايهَذارى براى آينده به اميد كسب مزيت رقابتى يايدار

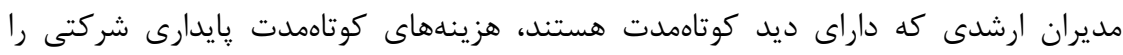

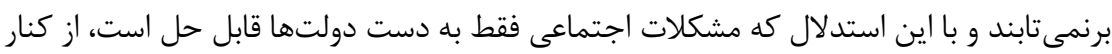

1. Sustainability Accounting Standards Board

2. Deloitte and Touche LLP

${ }^{3}$. American Institute of Certified Public Accountants 
دكتر خدامى يور و همكاران، تدوين و ارزيابى مدل موانع اجرا، افشا و استانداردَذارى يايدارى شركتى در ايران سبr

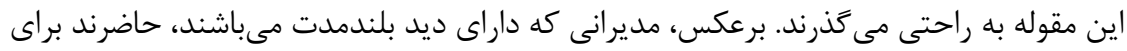

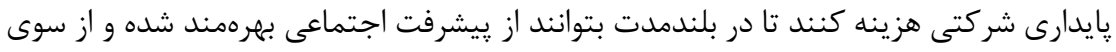
ديخر براى خود اعتبار و شهرت كسب كنند. براساس تئورىهاى ابزارى'، وظيفه شركتها تنها بيشينهسازى منافع اقتصادى است و اين دولتها و سازمانهاى عمومى هستند كه بر بايه اخذ ماليات، وظيفه دارند بر مسئوليتهاى اجتماعى نظارت داشته باشند و قوانين و قواعدى رائد را مشخص

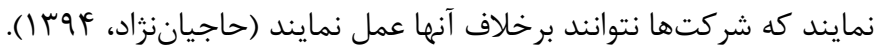

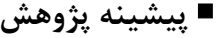

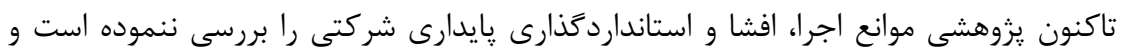

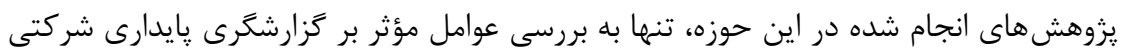

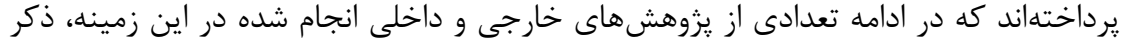
شده است.

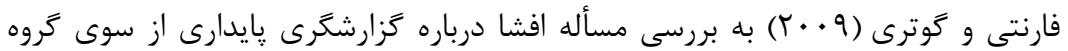

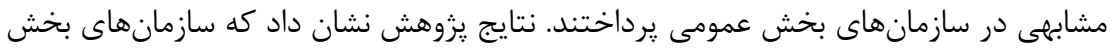

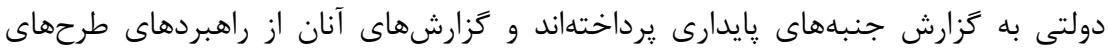

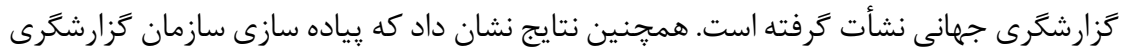
جهانى (GRI) ناقص بوده و سازمانها تنها بخشى از GRI را براى افشا انتخاب كردهاند. كراتن

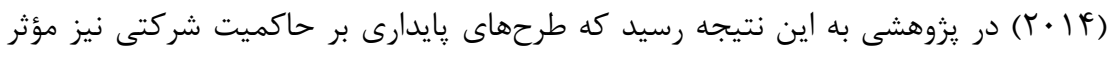

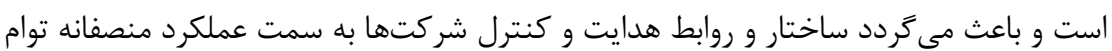

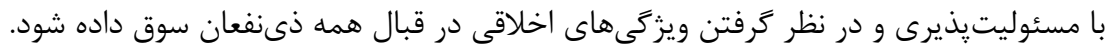

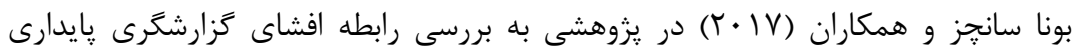

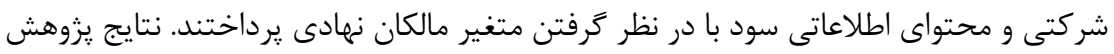

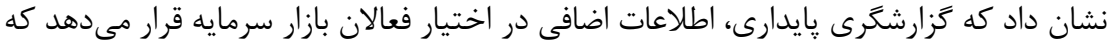

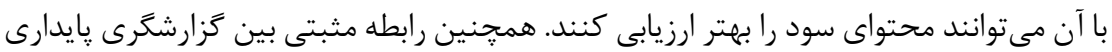

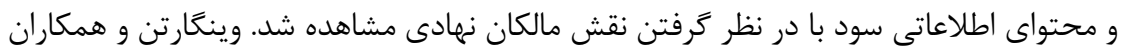

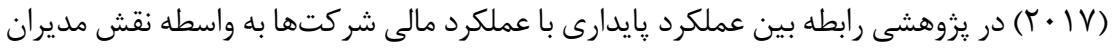

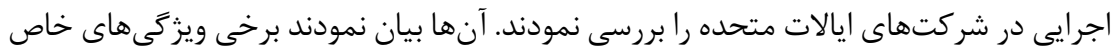

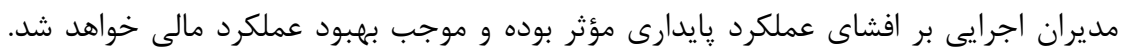

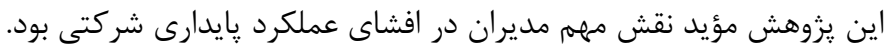

${ }^{1}$. Instrumental Theories

${ }^{2}$. Global Reporting Initiative (GRI) 


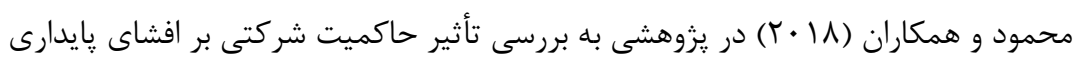

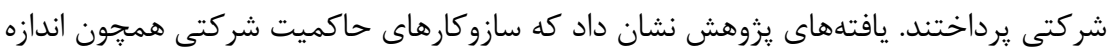

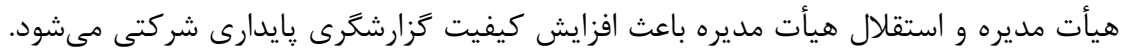

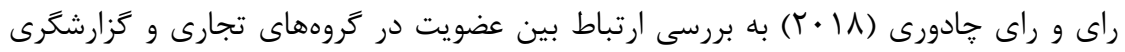

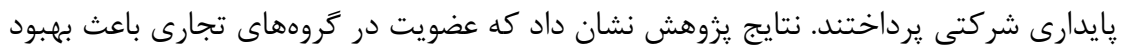

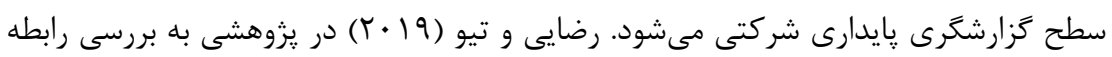

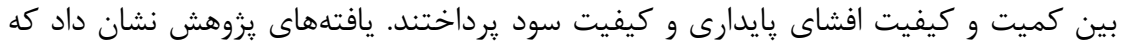

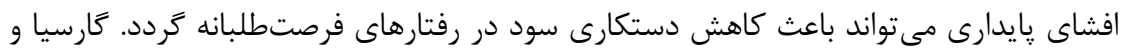

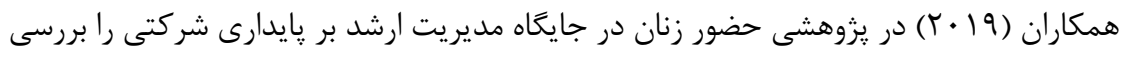

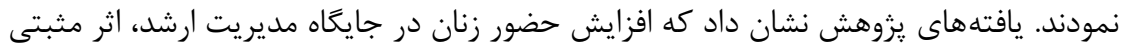

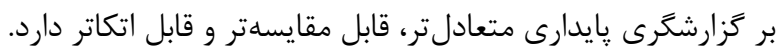

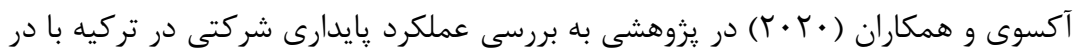

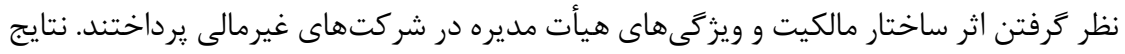

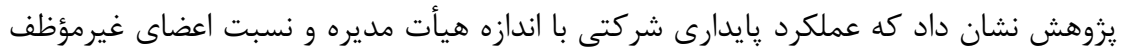

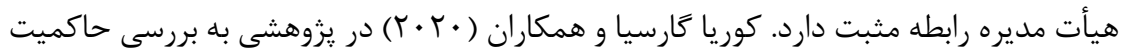

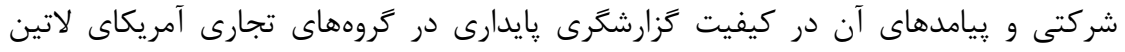

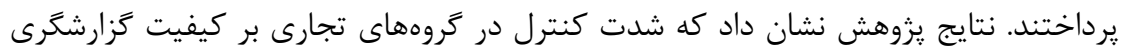

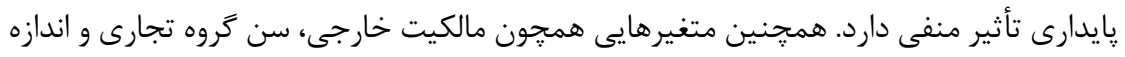

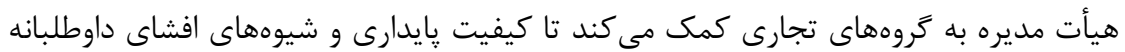

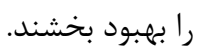

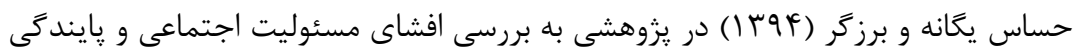

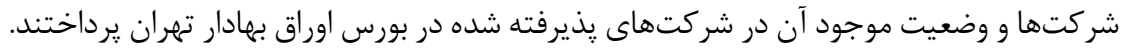

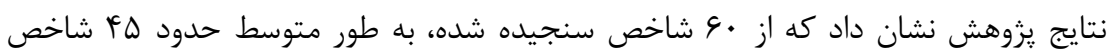

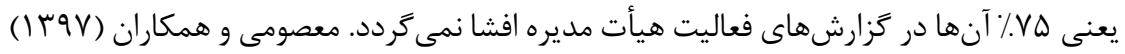

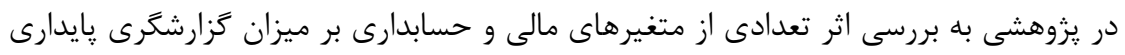

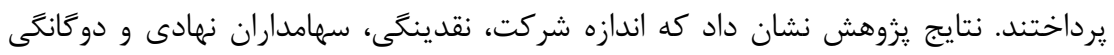

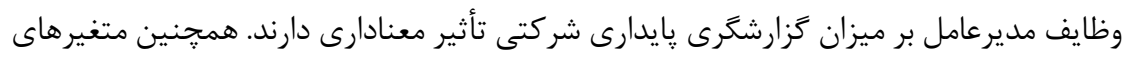

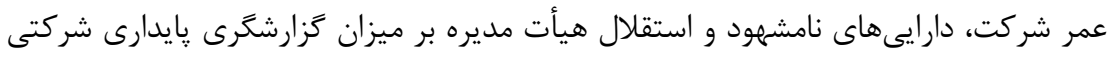

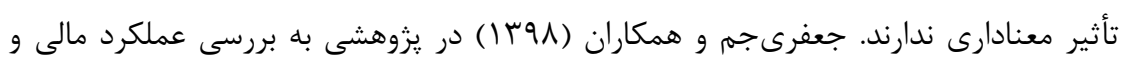

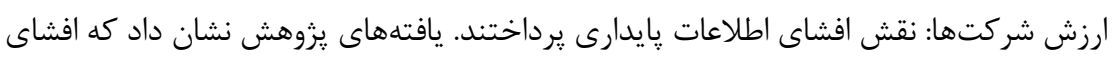


دكتر خدامى يور و همكاران، تدوين و ارزيابى مدل موانع اجرا، افشا و استانداردَذارى يايدارى شركتى در ايران

اطلاعات پايدارى با عملكرد مالى و ارزش شركتها رابطه معنادار و مستقيم دارد. همجنين

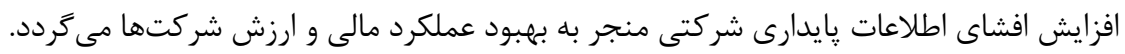

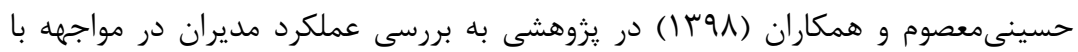

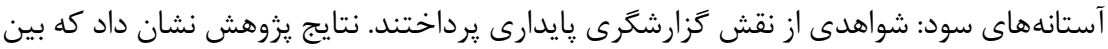

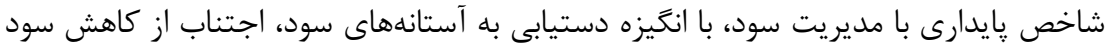

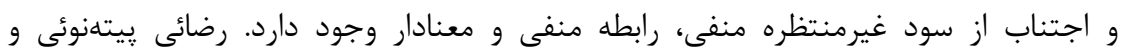

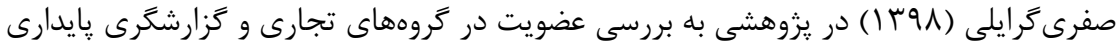

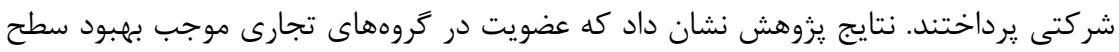

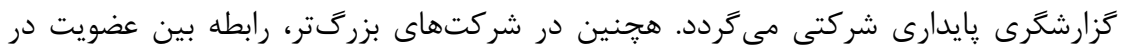
كروههاى تجارى و سطح گزارشكرى بايدارى، قوى

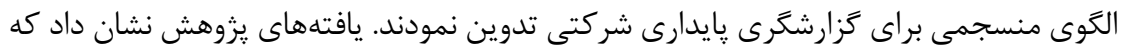

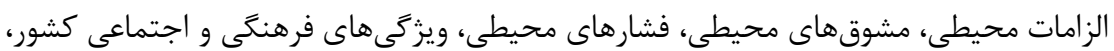

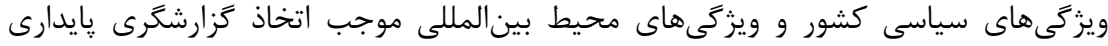

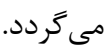

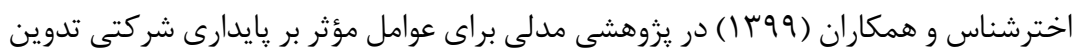

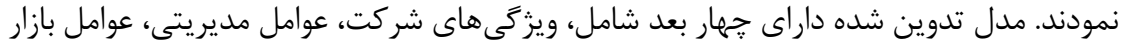

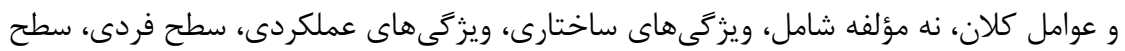

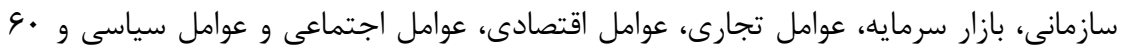

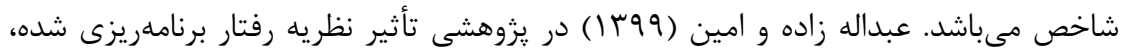

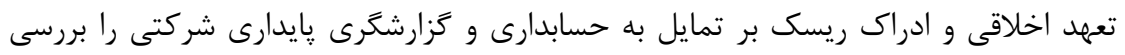

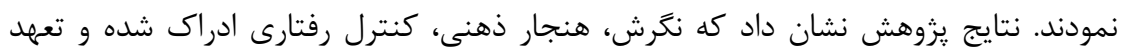

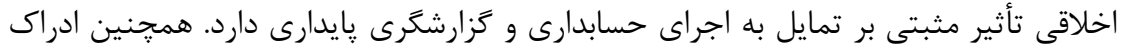

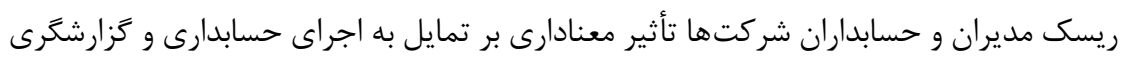

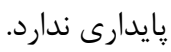

در يزوهشهاى پِيشين، بررسى پايدارى شركتى بدون در نظر كرفتن شرايط اقتصادى،

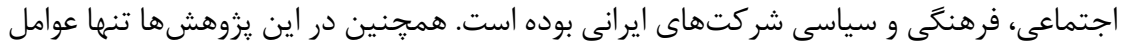

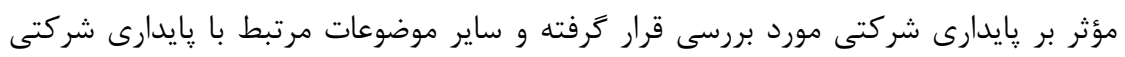

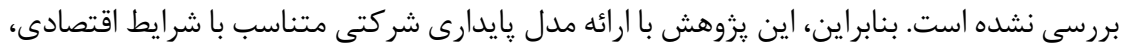

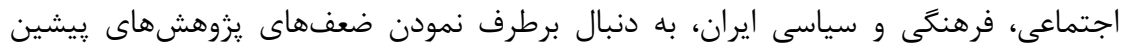

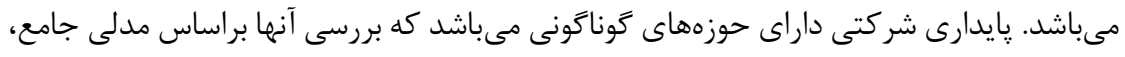


نتايج كاملتر و شفافترى در اختيار استفادهنندكان قرار مىدهد. در همين راستا، اين يزوهش

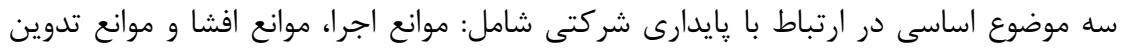

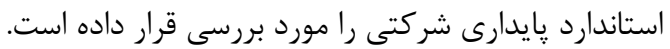

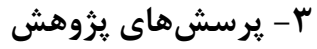

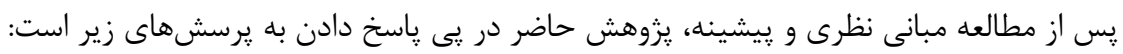

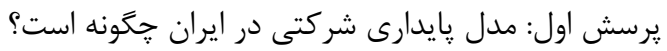

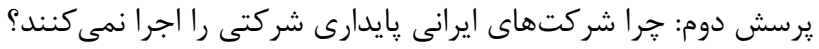

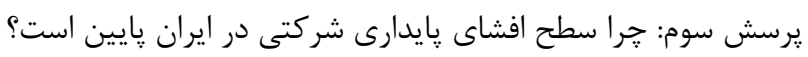

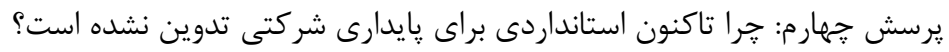

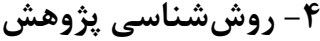

يزوهش حاضر از طرفى به دنبال تدوين مدلى براى يايدارى شركتى بوده، و از طرف ديكر مدل

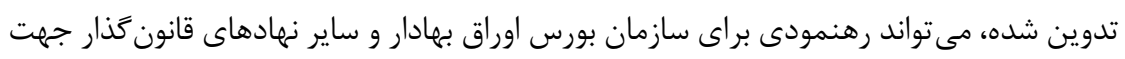

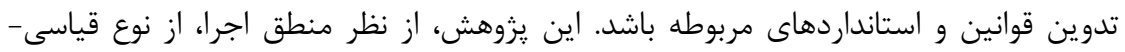

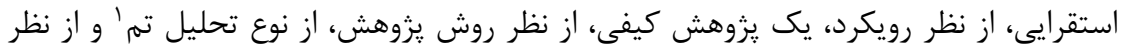

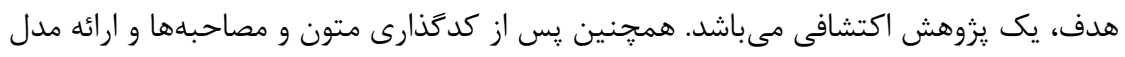
يزوهش، به منظور سنجش ميزان اعتبار و مقبوليت مدل تدوين شده از روش بِيمايشى و ابزار ير ترشنامه استفاده شده است.

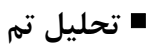

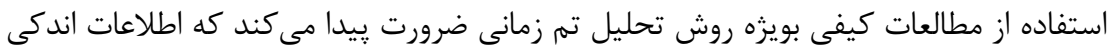
در مورد يديده مورد مطالعه وجود داشته باشد و يا اينكه در مطالعات و يزوهش هائهاى انجام شده

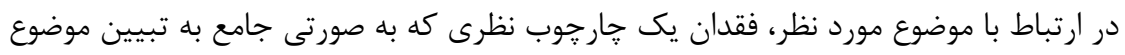

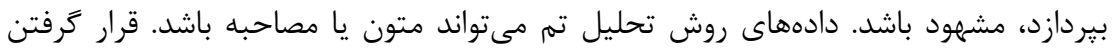
كدهاى مشابه در كنار يكديخر، به شكل

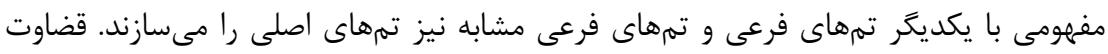

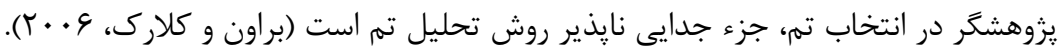

1. Thematic Analysis 
دكتر خدامى يور و همكاران، تدوين و ارزيابى مدل موانع اجرا، افشا و استانداردَّذارى يايدارى شركتى در ايران TrV

|

كدهاعبارتاند از ويزگگىاى از دادهها (معنايى يا محتوايى) كه براى تحليل، جالب به نظر مىرسند. كدها در كنار هم و در ييوند با هم، تمها را تشكيل مى دهند. در تعريف كدها سه عامل در نظر

كرفته مىشود:

عامل () حرف انگليسى، معرف نوع داده (متن يا مصاحبه) است كه كد با آن شروع مىشود. بر

$$
\text { اين اساس از علائم زير استفاده شده است: }
$$

متون بررسى شده؛ علامت T اختصار كلمه Text

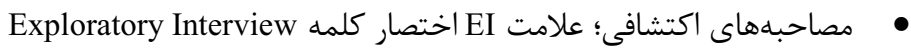

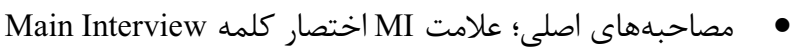

عامل ץ) شمارهى متون علمى يا فرد مصاحبه شونده است كه از ا • به بعد شمارهزارى شده

است.

عامل r) شمارهى كدهاى مربوط به يك متن علمى خاص يا يك نقل قول است كه از ا • به بعد

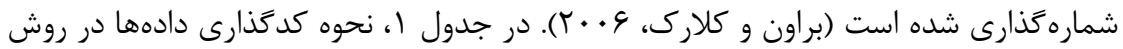

تحليل تم مشخص شده است.

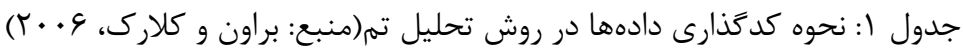

\begin{tabular}{|c|c|c|}
\hline 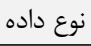 & شماره متون علمى يا فرد مصاحبه شونده & شماره كد در يك واحد تحليل \\
\hline $\mathrm{T}$ & إز از تا n & از از اتا n \\
\hline EI & از از ازا & از از ا تا n \\
\hline MI & از از تا & از از ا تا n \\
\hline
\end{tabular}

تروش و ابزار ترد آورى دادهها

دادهاى اين يزوهش از سه طريق زير كردآورى شده است:

الف) بررسى متون: ابتدا شش متن با استفاده از روش كتابخانهاى براى مرور ادبيات نظرى و

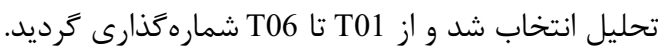

ب) انجام مصاحبه: در اين مرحله از ابزار مصاحبه نيمهساختاريافته استفاده شده و مصاحبهها در دو مرحله انجام شد. در مرحله اول، سه مصاحبه اكتشافى با متخصصين و صاحبنظران

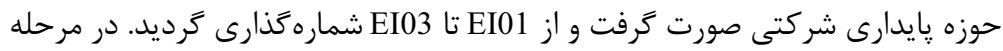

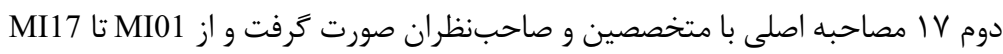

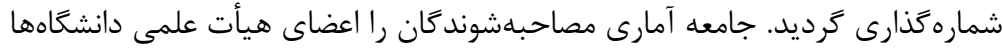

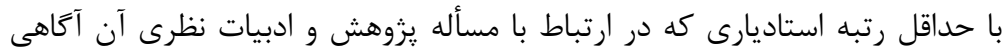
عميق و وسعت نظر دارند، تشكيل مى دهند. براى انتخاب افراد متخصص و صاحبنظر 
جهت انجام مصاحبهها از تركيب روشهاى غيرتصادفى (قضاوتى و گلوله برفى')

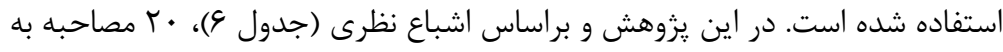

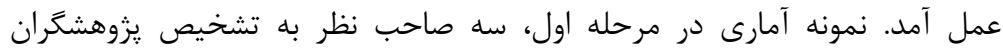

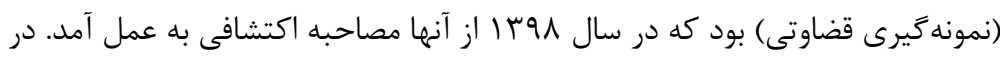

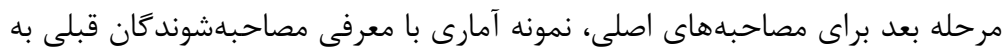

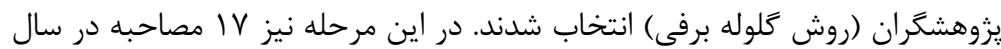

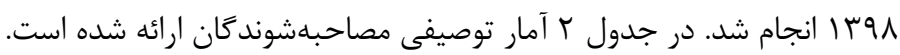
جدول r: آمار توصيفى مصاحبهشوندكان

\begin{tabular}{|c|c|c|c|c|c|}
\hline ميانگين فعاليت در امور اجرايى & هيأنگين عضويت در علمى (سال) & درصد & تعداد & \multicolumn{2}{|c|}{ مصاحبهشوندكان } \\
\hline tr & س & 10 & r & استاد & \multirow{3}{*}{ 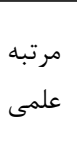 } \\
\hline r & tT & r. & f & دانشيار & \\
\hline $1 \cdot$ & 11 & $\Leftrightarrow \Delta$ & r & استايار & \\
\hline 11 & 19 & 90 & r & حسابدارى & \multirow{5}{*}{ تحصيلى } \\
\hline 1. & IV & 10 & r & اقتصاد & \\
\hline v & ir & $\Delta$ & 1 & مديريت & \\
\hline • & V & 1 . & r & روانشناسى & \\
\hline • & $\Delta$ & $\Delta$ & 1 & جامعهشناسى & \\
\hline 10 & IV & 9. & 11 & مرد & \multirow{2}{*}{ جنيست } \\
\hline IT & $1 \cdot$ & 1. & $r$ & زن & \\
\hline
\end{tabular}

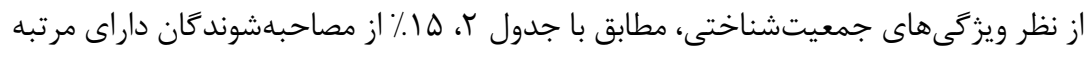

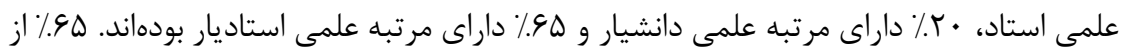

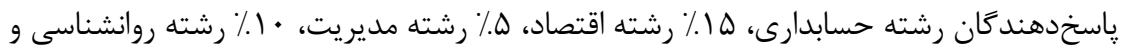

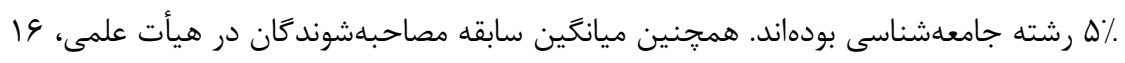

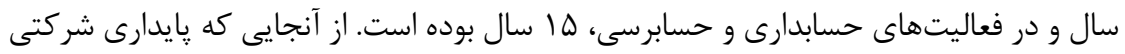

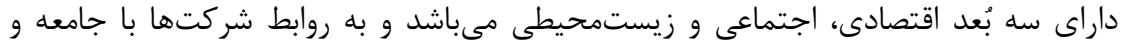

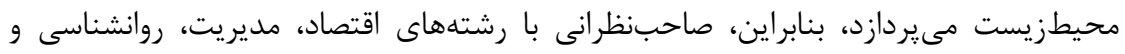

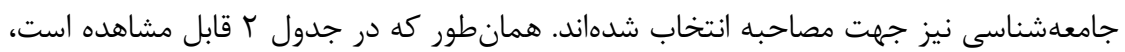

${ }^{1}$. Snowball 
دكتر خدامى يور و همكاران، تدوين و ارزيابى مدل موانع اجرا، افشا و استانداردَّذارى يايدارى شركتى در ايران وجr

افرادى جهت مصاحبه انتخاب شدهاند كه در حوزه پايدارى شركتى صاحبنظر بوده و در محيط آكادميك و فعاليتهاى اجرايى حسابدارى و حسابرسى داراى سابقه زيادى بودهاند.

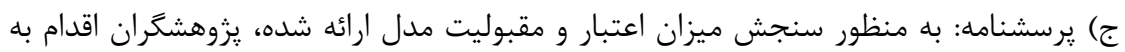

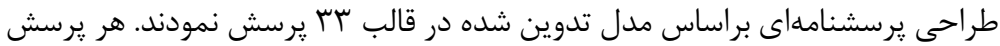

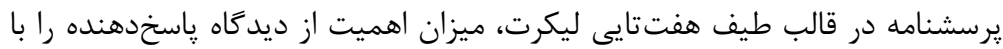

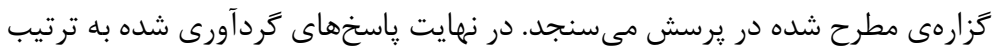

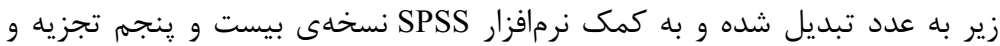
تحليل شده است.

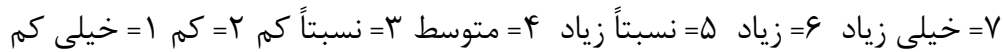

جامعه آمارى ياسخدهندگان يرسشنامه را متخصصين و صاحبنظرانى تشكيل مىدهند كه با

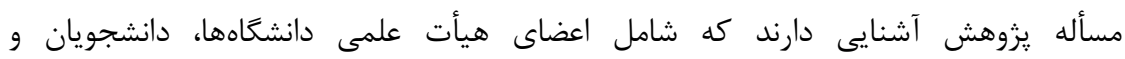

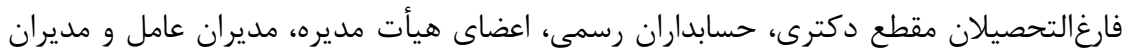

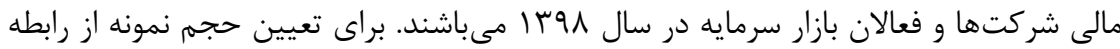

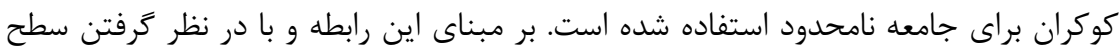

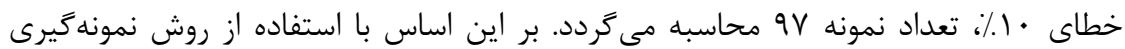
غيرتصادفى (قضاوتى) جهت انتخاب هدفمند باسخدهندكان، براى

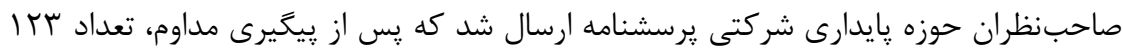

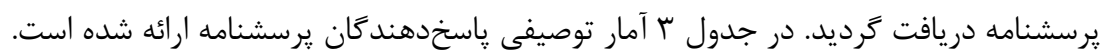
جدول r: آمار توصيفى ياسخدهند آنان يرسشنامه

\begin{tabular}{|c|c|c|c|c|c|c|c|c|c|}
\hline \multicolumn{2}{|c|}{ فرال بازار } & \multicolumn{2}{|c|}{ حسابدارى و حسابرسى امور اجرايى } & \multicolumn{2}{|c|}{ عضو هيأت علمى } & \multicolumn{2}{|c|}{ جمع كل } & \multirow{2}{*}{\multicolumn{2}{|c|}{ متخصصين }} \\
\hline كل & جزء & كل & جزء & كل & جزء & كل & جزء & & \\
\hline \multirow{2}{*}{$r V$} & If & \multirow{2}{*}{ m } & 10 & \multirow{2}{*}{90} & $\Delta \cdot$ & \multirow{2}{*}{ Irr } & vq & دكترى & \multirow{2}{*}{ تحصيلى } \\
\hline & r & & 19 & & 10 & & pr & كارشناسى ارشد & \\
\hline \multirow{4}{*}{ rV } & TV & \multirow{4}{*}{ rI } & TV & \multirow{4}{*}{90} & 91 & \multirow{4}{*}{ r } & 110 & حسابدارى & \multirow{4}{*}{ تحصيلى } \\
\hline & - & & - & & 1 & & 1 & مالى & \\
\hline & $\cdot$ & & $r$ & & $r$ & & $\Delta$ & اقتصاد & \\
\hline & $\cdot$ & & $r$ & & · & & $r$ & مديريت & \\
\hline \multirow{2}{*}{ TV } & Tr & \multirow{2}{*}{ r } & rt & \multirow{2}{*}{$9 \Delta$} & $\Delta \varphi$ & \multirow{2}{*}{$1 \pi r$} & $1 \cdots$ & مرد & \multirow{2}{*}{ جنيست } \\
\hline & $\Delta$ & & 9 & & 9 & & $r \mu$ & زن & \\
\hline
\end{tabular}




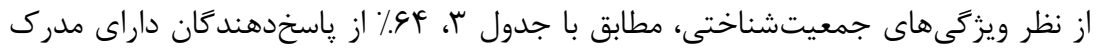

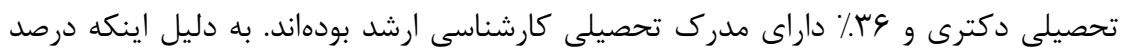

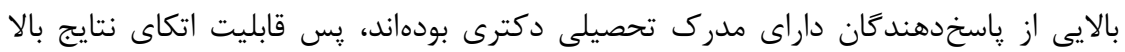

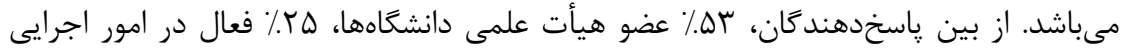

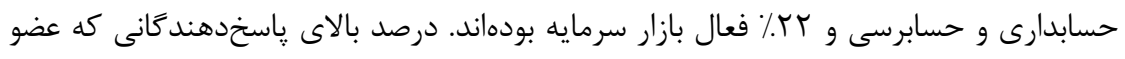

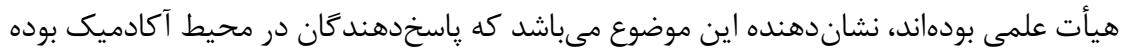

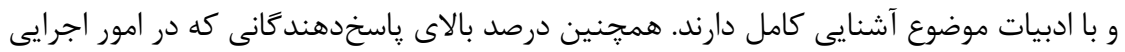

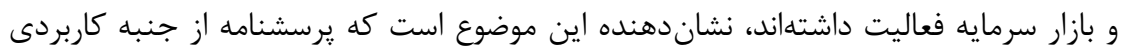

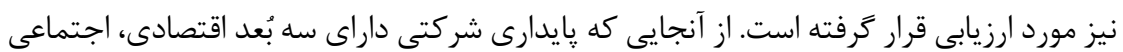
و زيستمحيطى مىباشد و به روابط شركتها با جامعه و محيطزيست مى يردازد، بنابراين،

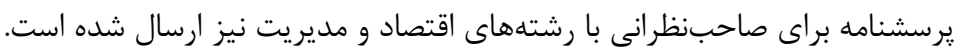

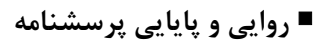

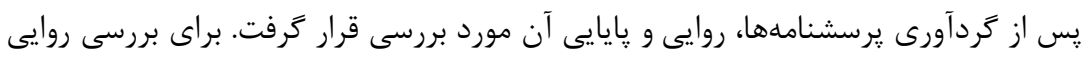

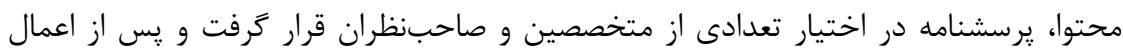

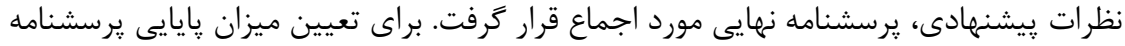

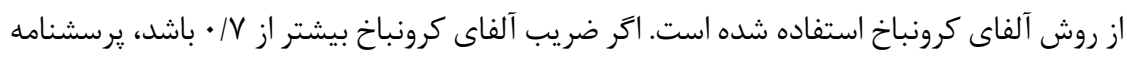

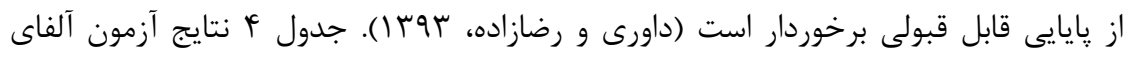

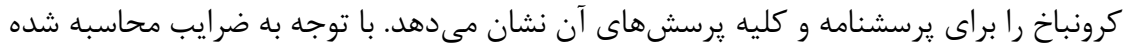

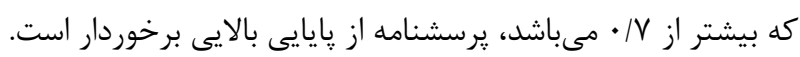

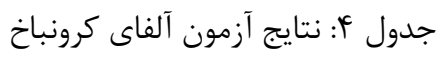

\begin{tabular}{|c|c|c|c|}
\hline يايايى & ضريب آلفاى كرونباخ & تعداد يرسشها : & عنوان يرسشها \\
\hline 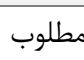 &.$/ 9 Y \wedge$ & 11 & موانع اجراى پايدارى شركتى \\
\hline 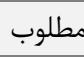 & .1914 & 11 & موانع افشاى پايدارى شركتى \\
\hline 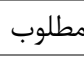 & - INAF & r & موانع تدوين استاندارد پايدارى شركتى \\
\hline
\end{tabular}

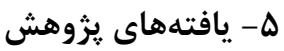

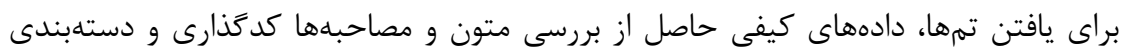

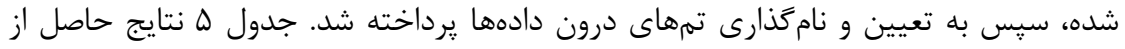

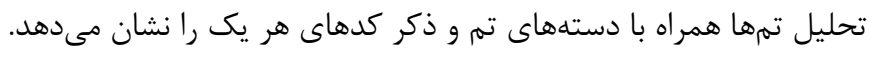


دكتر خدامى يور و همكاران، تدوين و ارزيابى مدل موانع اجرا، افشا و استانداردَذارى يايدارى شركتى در ايران اسب

\begin{tabular}{|c|c|c|c|}
\hline \multicolumn{4}{|c|}{ جدول ه: تحليل تم همراه با كدهاى هر تم } \\
\hline كدها & تمهاى جزئى & تمرهاى & تملهاى \\
\hline 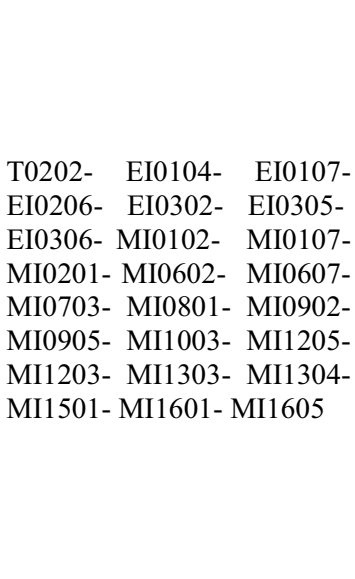 & 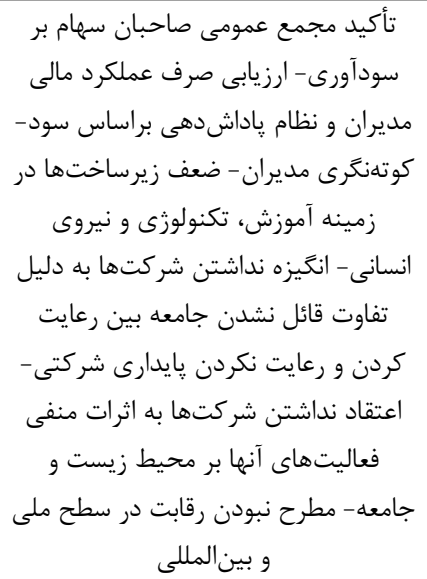 & 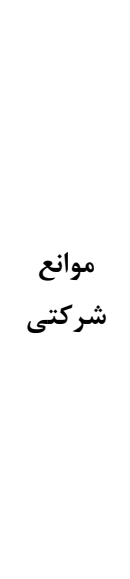 & \multirow{5}{*}{$\begin{array}{l}\frac{2}{2} \\
\frac{2}{4} \\
\frac{3}{3} \\
\frac{3}{5} \\
3 \\
3 \\
3\end{array}$} \\
\hline $\begin{array}{lrr}\text { T0102- } & \text { T0502- } & \text { T1414- } \\
\text { T1511- } & \text { T1714- } & \text { T1820- } \\
\text { T1916- } & \text { EI0106- } & \text { EI0204- } \\
\text { MI0202- } & \text { MI0301- } & \text { MI0403- } \\
\text { MI0603- } & \text { MI0702- } & \text { MI0806- } \\
\text { MI1006- } & \text { MI1207- } & \text { MI1402- } \\
\text { MI1604- } & \text { MI1707 } & \\
\end{array}$ & وضعيت مالى نامناسب شركتها- بالا & موانع مالى & \\
\hline $\begin{array}{lrr}\text { T0103- } & \text { T0301- } & \text { T0602- } \\
\text { T1915- } & \text { EI0103- } & \text { EI0308- } \\
\text { MI0105- } & \text { MI0601- } & \text { MI0701- } \\
\text { MI0906- } & \text { MI1005- } & \text { MI1206- } \\
\text { MI1307- } & \text { MI1308- } & \text { MI1502- } \\
\text { MI1701 } & \end{array}$ & 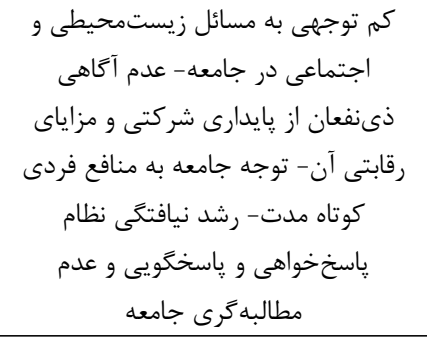 & اجتماعى & \\
\hline $\begin{array}{lrr}\text { T0201- } & \text { T0401- } & \text { T0501- } \\
\text { T0601- } & \text { EI0101- } & \text { EI0207- } \\
\text { MI0106- } & \text { MI0501- } & \text { MI0704- } \\
\text { MI0901- MI1404- }\end{array}$ & 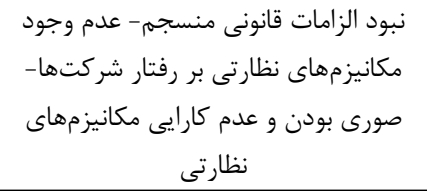 & 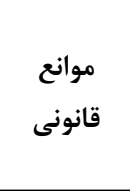 & \\
\hline $\begin{array}{lrr}\text { T1415- } & \text { T1514- } & \text { T1713- } \\
\text { T1917- } & \text { MI0404- } & \text { MI1301- } \\
\text { MI1702 } & & \\
\end{array}$ & حمايت دولت از صنايع انحصارى- سهمه & 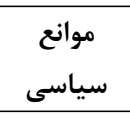 & \\
\hline
\end{tabular}




\begin{tabular}{|c|c|c|c|}
\hline $\begin{array}{lrr}\text { T0101- } & \text { T1513- } & \text { T1617- } \\
\text { T1715- } & \text { T1918- } & \text { EI0203- } \\
\text { EI0304- } & \text { EI0310- } & \text { MI0104- } \\
\text { MI0304- } & \text { MI0604- } & \text { MI0605- } \\
\text { MI0804- } & \text { MI1002- } & \text { MI1201- } \\
\text { MI1306- } & \text { MI1403- } & \text { MI1503- } \\
\text { MI1505- MI1506- } & \text { MI1705 }\end{array}$ & 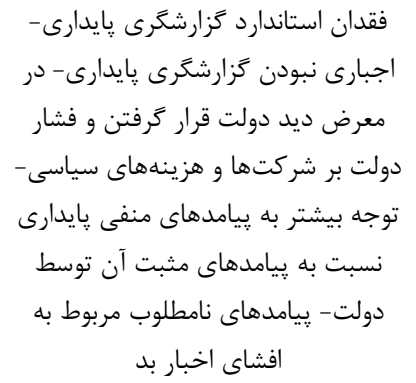 & كزارشع موانع & $\frac{9}{2}$ \\
\hline $\begin{array}{lll}\text { T1413- } & \text { T1616- } & \text { EI0202- } \\
\text { EI0205- } & \text { EI0301- } & \text { EI0309- } \\
\text { MI0401- MI0705- MI0802- } \\
\text { MI0803- MI0904- MI1004- } \\
\text { MI1202- MI1305- MI1401- } \\
\text { MI1602- MI1704- MI1706 }\end{array}$ & 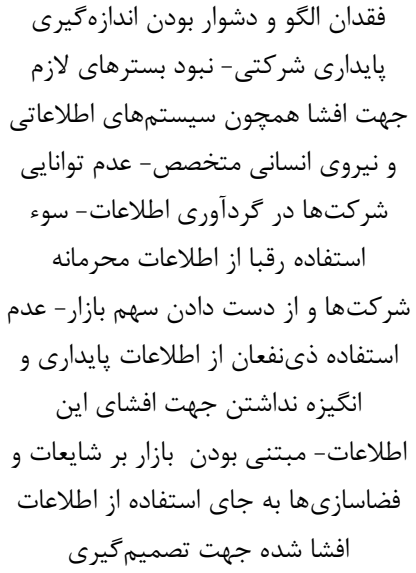 & عراضه & 要 \\
\hline 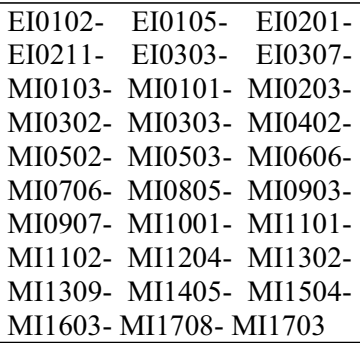 & 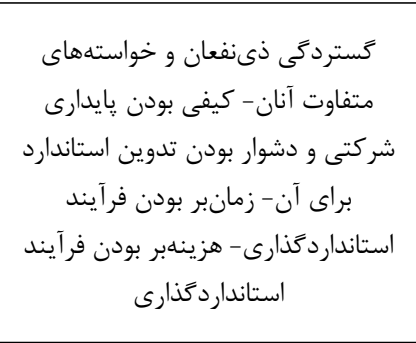 & كلان & 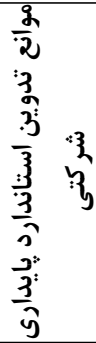 \\
\hline
\end{tabular}

منبع: يافتههاى يزوهشكر

$$
\begin{aligned}
& \text { تهم اصلى اول: موانع اجراى يايدارى شركتى } \\
& \text { هيج دستورالعمل از قبل تعيين شدهاى براى آن وجود ندارد (EI0207). } \\
& \text { بايد زيرساختهاى لازم براى يُادهسازى وجود داشته باشد. زيرساختها همجون افراد } \\
& \text { متخصص، سيستمهاى اطلاعاتى و كامييوترى و تكنولوزىهاى ييشرفته (MI0101). }
\end{aligned}
$$

نبود قوانين و مقررات الزامآور باعث مى شود كه مديران رغبت كمترى ييدا كنند (MI1404). 
دكتر خدامى يور و همكاران، تدوين و ارزيابى مدل موانع اجرا، افشا و استانداردكَذارى بايدارى شركتى در ايران بس؟

عدم اطلاع اعضاى هيأت مديره از مزاياى بايدارى و اينكه آكاهى در اين خصوص ندارند، باعث مىشود هيج رغبتى براى اجراى آن نداشته باشند (EI0103).

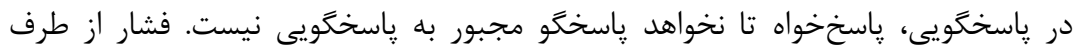
ياسخخواه خيلى مهم است، خواست جامعه و ذيىنفعان خيلى تأثير دارد (EI0308).

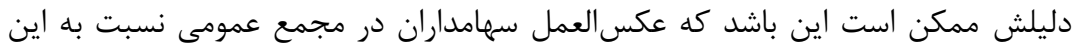
موضوع منفى مىباشد (MI0703). شايد يكى از دلايلى كه در ايران، شركتها كمتر به دنبال آن مىروند، همين بحث رقابت رابت

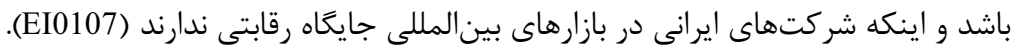

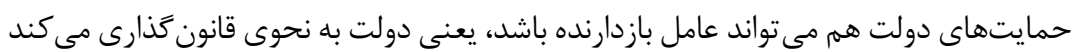

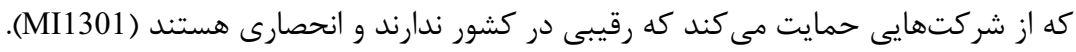

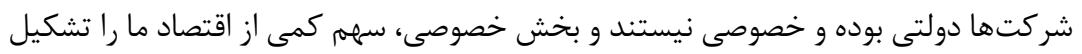

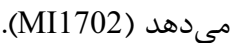

\section{تم اصلى دوم: موانع افشاى هيايدارى شركتى}

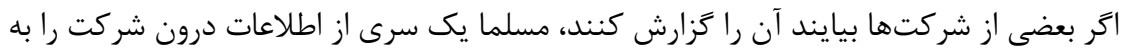

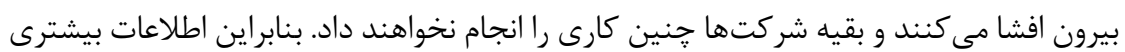
در اختيار رقبا قرار مى دهند و آنان ممكن است سوء استفاده كنند (MI0705).

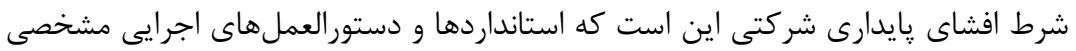

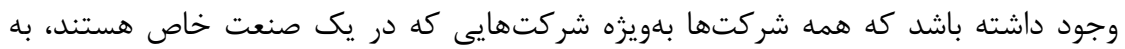
شكلى واحد كزارشكَى را انجام دهند (MI0803). اكر حار جوب قانونى وجود نداشته باشد و حداقل الز الزاماتى دارئ در قالب قوانين و استانداردها تدوين نشود كه همه شركتها ملزم به افشاى بايدارى شوند (EI0207). سرمايه كذاران به افشاى بايدارى شركتى توجه زيادى نمى كنند. بازار سرمايه بيشتر مبتنى

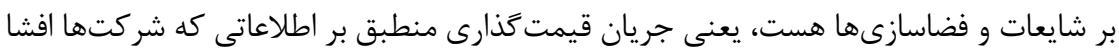

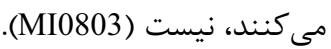
جار جوب و مدلى براى افشاى آن در كشور ايران وجود ندارد (MI0401). (MI080).

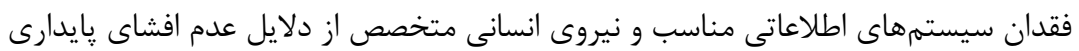

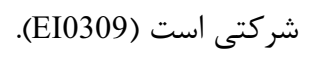




=
تم اصلى سوم: موانع تدوين استاندارد پِايدارى شركتى

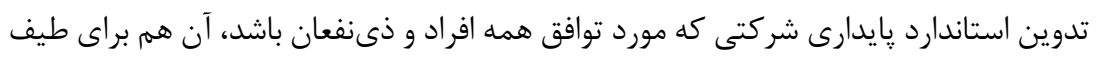

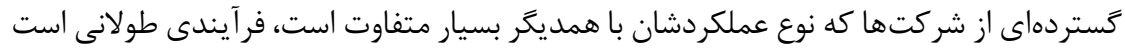
و نياز به هزينهاى زيادى دارد (EI0105, EI0102). با توجه به محدوديتهاى پايدارى شركتى، تدوين ارد استاندارد براى آن كار سختى مىباشد

(MI0503)

تدوين استاندارد متناسب ايران، با توجه به گستردگى ذىنفعان، فرآيندى زمانبر مىباشد

\section{اشباع نظرى دادهها}

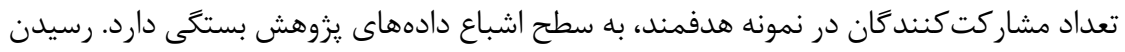

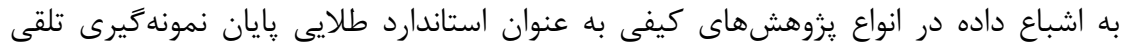

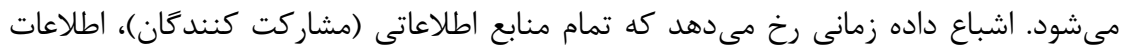

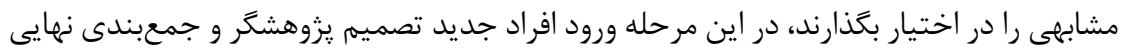

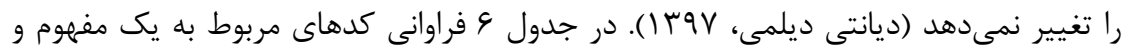

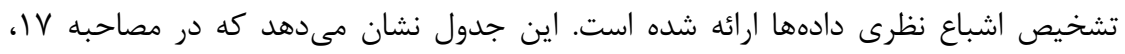

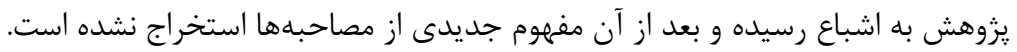
جدول 9: فراوانى كدهاى مربوط به يك مفهوم و تشخيص اشباع نظرى دادهانها

\begin{tabular}{|c|c|c|c|c|c|c|c|c|c|c|c|c|c|c|c|c|}
\hline \multicolumn{15}{|c|}{ توزيع فراوانى كدهاى مربوط به يك مفهوم (شاخص) } & \multirow{2}{*}{ مفهوم (تمهاى جزئى) } & \multirow{2}{*}{$\begin{array}{l}3 \\
3 \\
3 \\
3 \\
4 \\
y\end{array}$} \\
\hline 马 & 20 & $\leq$ & $\geq \underline{a}$ & $=3$ & 2 & $=2$ & $==$ & $\dot{-} 0$ & $\sigma<$ & $=>$ & $a c$ & 84 & 2 & 2 & & \\
\hline$r$ & & & & & & * & & & & & & $*$ & & & تأكيد مجمع عمومى صاحبان & \\
\hline$r$ & * & & & * & & & $*$ & & & & & & & & 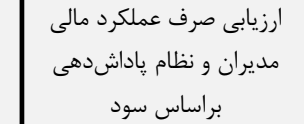 & \\
\hline$F$ & & & * & & & & & * & $\%$ & & & & $*$ & * & كوتهنكَى مديران & $\frac{2}{2}$ \\
\hline \& & & $*$ & & & & * & & $*$ & & $*$ & * & * & & ; & \# آموزش، زيرساختها در زمينه & y \\
\hline F & $*$ & & & * & & & & & * & & & $*$ & & & 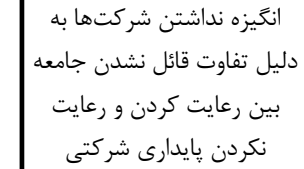 & \\
\hline
\end{tabular}


دكتر خدامى يور و همكاران، تدوين و ارزيابى مدل موانع اجرا، افشا و استانداردكذارى يايدارى شركتى در ايران هبr

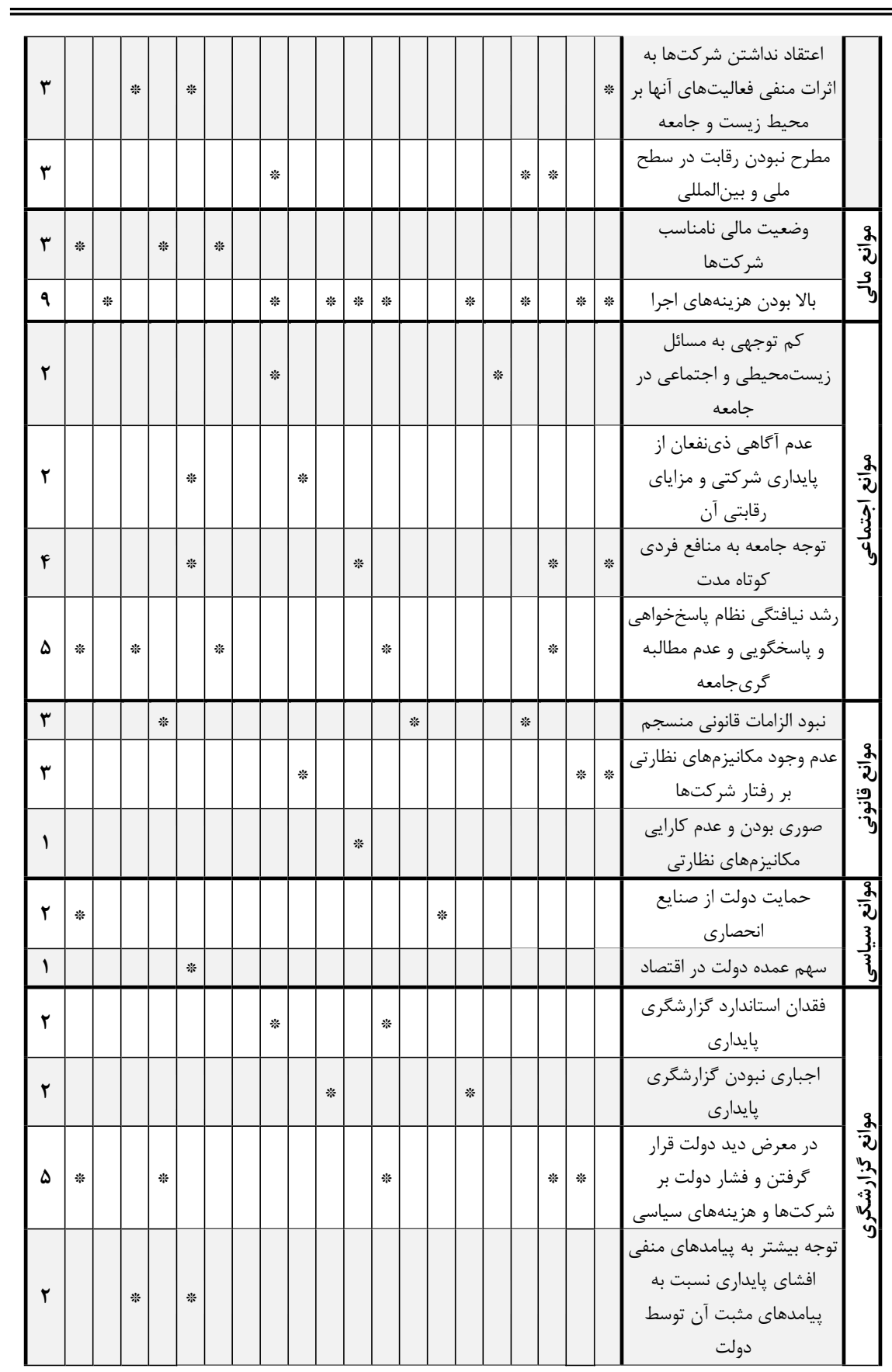




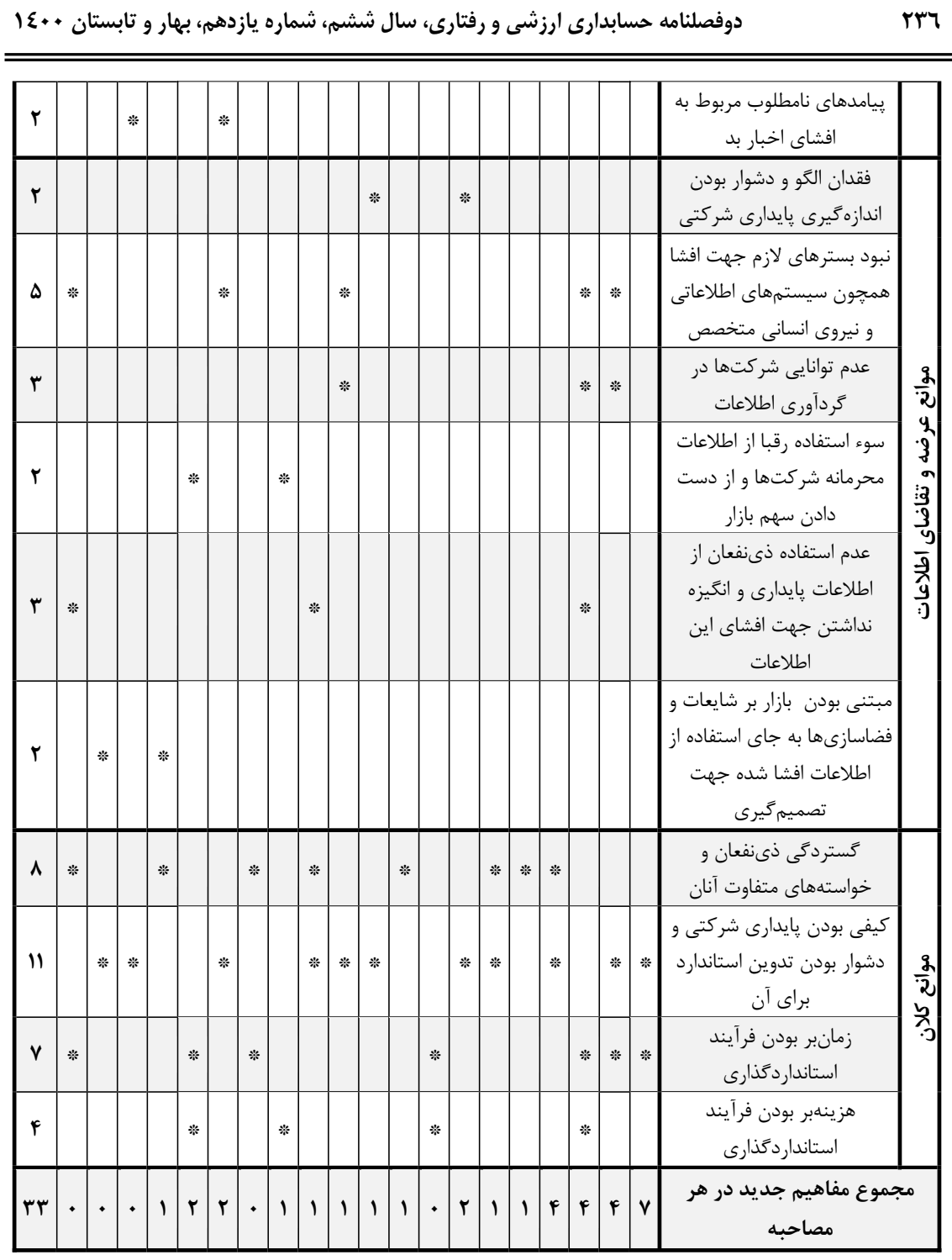

منبع: يافتههاى يزوهشكر

مدل يزوهش براساس نتايج حاصل از كدكذارى متون و مصاحبهها با استفاده از روش تحليل تمه، تدوين و در شكل الرائه شده است. 
شكل ا: مدل موانع اجرا، افشا و استانداردكذارى يايدارى شركتى در ايران

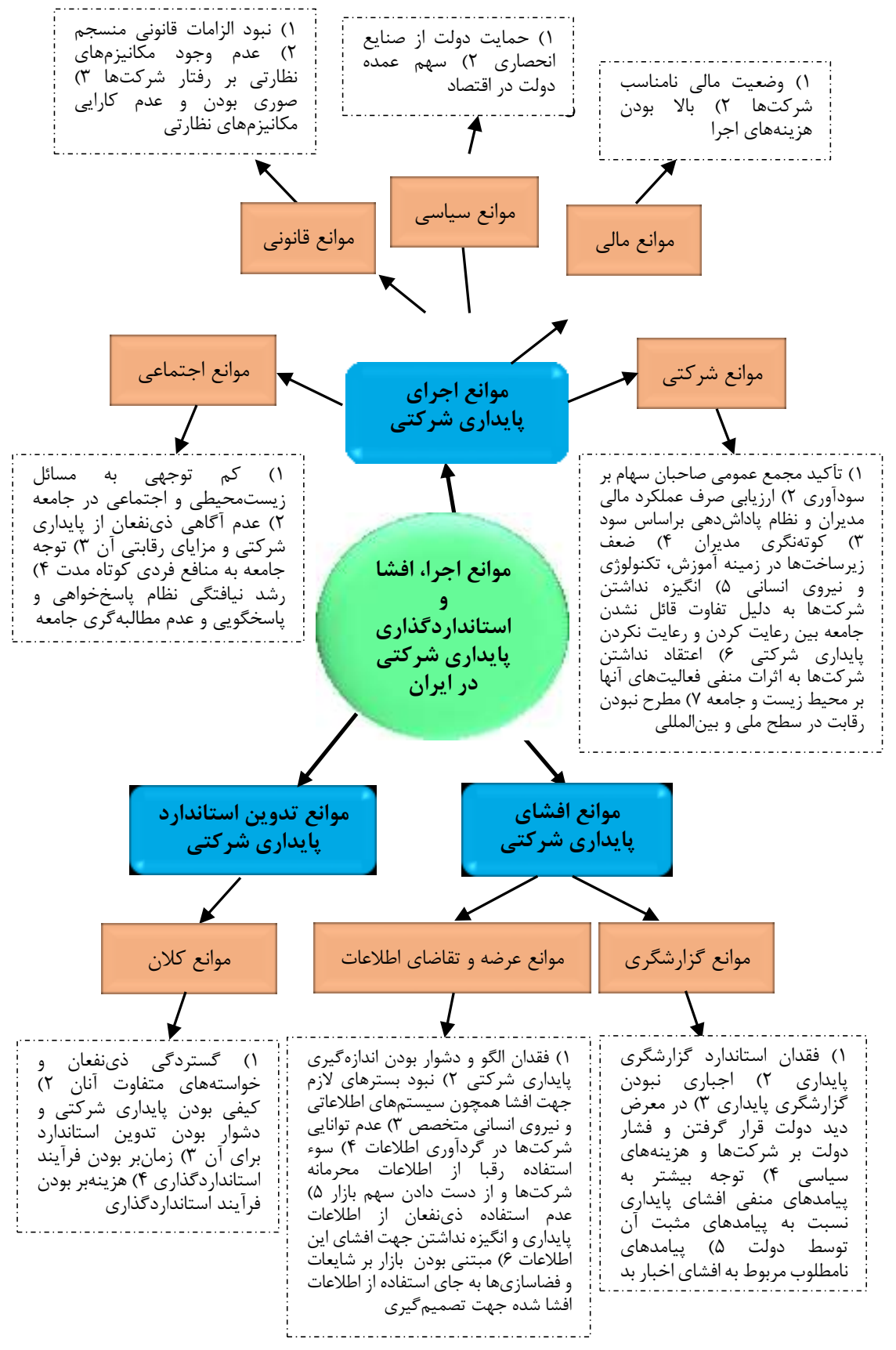


بسيارى از نويسندكان براساس يك قاعده سرانشَتى معتقدند كه صرفنظر از توزيع جامعه

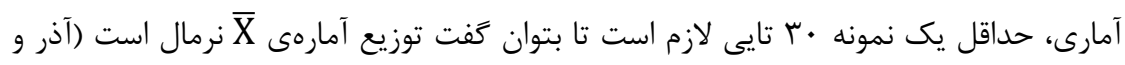

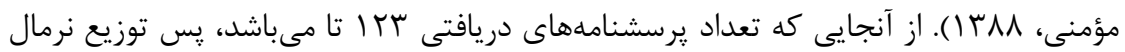

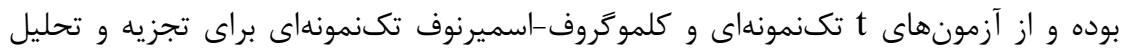

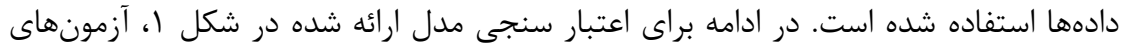
آمارى مرتبط با هر يرسش بزوهش ارائه شده است.

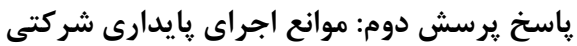

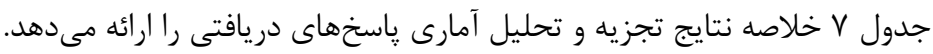

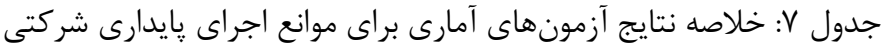

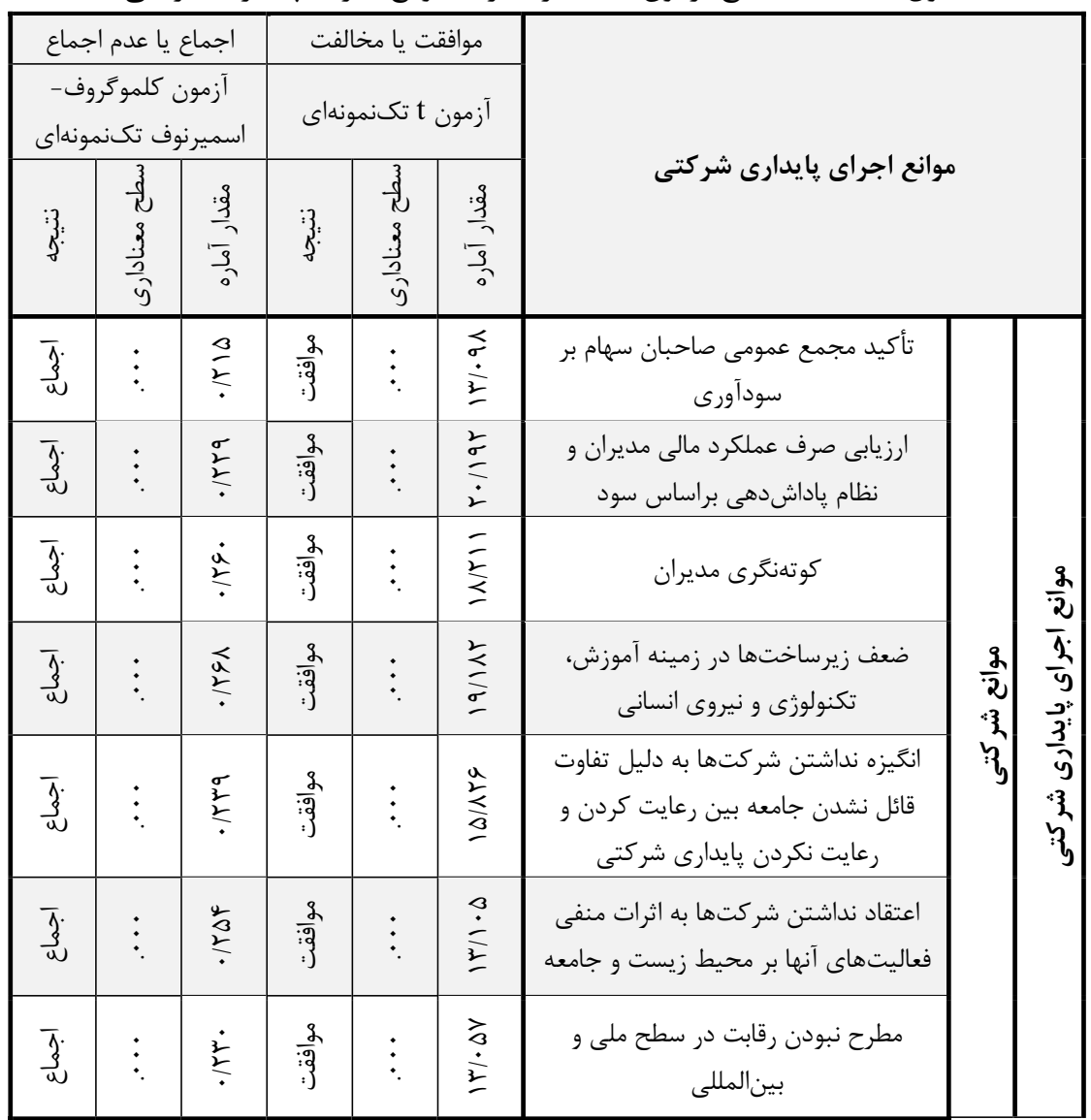


دكتر خدامى يور و همكاران، تدوين و ارزيابى مدل موانع اجرا، افشا و استانداردكذارى يايدارى شركتى در ايران وسج

\begin{tabular}{|c|c|c|c|c|c|c|c|}
\hline$\overline{3}$ & $\bullet$ & $\begin{array}{l}a \\
2 \\
2 \\
2\end{array}$ & $\frac{2}{9}$ & $\vdots$ & $\begin{array}{l}\frac{y}{y} \\
\frac{\sigma}{2} \\
\frac{2}{2}\end{array}$ & وضعيت مالى نامناسب شركتها & \multirow{2}{*}{$\begin{array}{l}\frac{g}{2} \\
\frac{9}{3}\end{array}$} \\
\hline$\overline{3}$. & $\vdots$ & a & $\frac{2}{9}: 9$ & $\vdots$ & $\underset{\frac{\sigma}{a}}{\underline{a}}$ & بالا بودن هزينه هاى اجرا & \\
\hline$\overline{3}$. & $\vdots$ & 2 & $\frac{2}{9}$ & $\vdots$ & $\begin{array}{l}a_{a} \\
\frac{y}{a} \\
\underline{y}\end{array}$ & 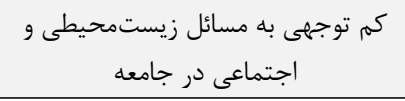 & \multirow{4}{*}{$\frac{\frac{9}{2}}{\frac{1}{3}}$} \\
\hline$\overline{3}$ & $\vdots$ & $\frac{3}{2}$ & $\frac{2}{9}: 3$ & $\vdots$ & $\frac{a}{a}$ & 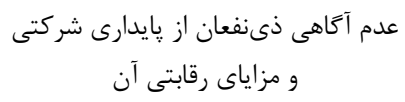 & \\
\hline$\frac{\pi}{3}$ & $\vdots$ & $\begin{array}{l}\frac{3}{4} \\
\frac{2}{2} \\
2\end{array}$ & $\frac{2}{9}$ & $\vdots$ & $\frac{a}{3}$ & توجه جامعه به منافع فردى كوتاه مدت & \\
\hline$\overline{3}$ & $\vdots$ & $\frac{\sigma}{2}$ & $\frac{2}{9}$ & $\vdots$ & $\frac{2}{\frac{2}{3}}$ & 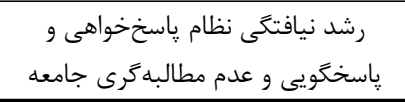 & \\
\hline$\overline{3}$ & $\vdots$ & $\begin{array}{l}\sigma \\
2 \\
2 \\
\end{array}$ & $\frac{2}{9}$ & $\vdots$ & $\begin{array}{l}a \\
\frac{a}{\sigma} \\
\frac{\sigma}{\geq}\end{array}$ & نبود الزامات قانونى منسجم & \multirow{3}{*}{$\begin{array}{l}\frac{9}{2} \\
: \frac{9}{3} \\
3\end{array}$} \\
\hline$\overline{3}$ & $\vdots$ & $\frac{2}{2}$ & $\frac{2}{9}$ & $\vdots$ & $\frac{\dot{y}}{a}$ & عدم وجود مكانيزمهاى نظارتى بر رفتار & \\
\hline$\frac{\pi}{3}$ & : & $\frac{3}{2}$ & $\frac{2}{9}$ & $\vdots$ & $\stackrel{2}{a}$ & صورى بودن و عدم كارايى مكانيزمهاى & \\
\hline$\overline{3}$ & $\vdots$ & $\frac{2}{2}$ & $\frac{2}{9}$ & $\vdots$ & $\begin{array}{l}b \\
\frac{b}{a} \\
\underline{a}\end{array}$ & حمايت دولت از صنايع انحصارى & \multirow{2}{*}{$\begin{array}{l}\frac{9}{2} \\
3 \\
3 \\
3\end{array}$} \\
\hline$\frac{\pi}{3}$ & $\vdots$ & $\sum$ & $\frac{2}{9}$ & $\vdots$ & $\frac{\sum^{y}}{a}$ & سهم عمده دولت در اقتصاد & \\
\hline
\end{tabular}

منبع: يافتههاى يزوهشكر

همانطور كه در جدول V مشاهده مىشود، براى كليه شاخصها، سطح معنادارى كمتر از

ه • • بوده و ميانگين امتيازات با خطاى بسيار كم، بالاتر از جهار مىباشد. بنابراين در سطح

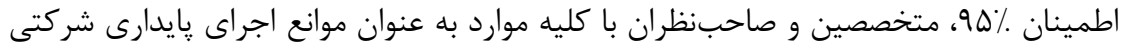
موافق بودهاند. براى تشخيص وجود يا عدم وجود اجماع درون گروهى در بين نظرات متخصصين و صاحبنظران راجع به شاخصهاى مطرح شده در يرسشنامه، از آزمون كلموگروف-اسميرنوف تكنمونهاى استفاده شده است. مطابق جدول بالا براى كليه شاخصهاى دار داراى ياسخ موافق در

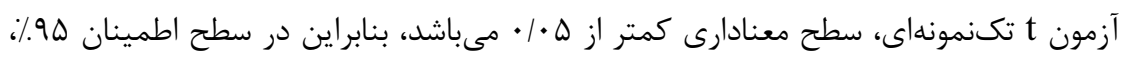
اجماع درون گروهى در مورد كليه شاخصها وجود دارد.

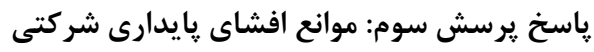

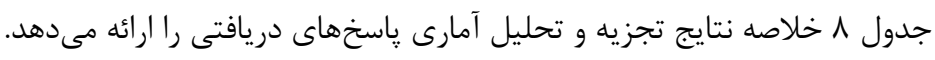




\begin{tabular}{|c|c|c|c|c|c|c|c|c|}
\hline \multicolumn{9}{|c|}{ جدول ^: خلاصه نتايج آزمونهاى آمارى براى موانع افشاى پايدارى شركتى } \\
\hline \multirow{2}{*}{\multicolumn{3}{|c|}{ 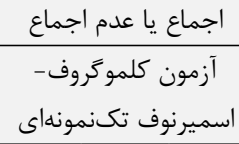 }} & \multirow{2}{*}{\multicolumn{3}{|c|}{ آز موافقت يا مخالفت }} & \multirow{3}{*}{\multicolumn{2}{|c|}{ موانع افشاى پايدارى شركتى }} & \\
\hline & & & & & & & & \\
\hline :3: & $\begin{array}{l}3 \\
3 \\
3 \\
3 \\
3 \\
3 \\
5\end{array}$ & $\overbrace{\substack{3 \\
3}}^{\frac{8}{3}}$ & $3:$ & $\begin{array}{c}3 \\
-3 \\
3 \\
3 \\
3 \\
y\end{array}$ & $\frac{1}{3}$ & & & \\
\hline$\frac{\pi}{3}$ & $\vdots$ & $\frac{\sigma}{2}$ & $\frac{2}{9}$ & $\vdots$ & $\begin{array}{l}\sigma \\
\frac{\sigma}{\sigma} \\
\underline{\alpha}\end{array}$ & فقدان استاندارد كَزارشخرى يايدارى & \multirow{11}{*}{ 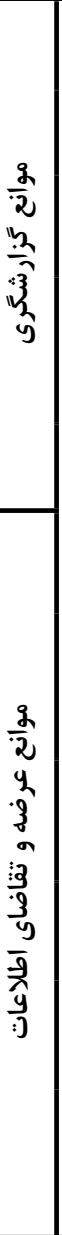 } & \\
\hline$\overline{3}$. & $\vdots$ & $\stackrel{\dot{i}}{2}$ & $\frac{2}{9}$ & $\vdots$ & $\begin{array}{l}\frac{y}{y} \\
\frac{y}{2} \\
\geq \\
\geq\end{array}$ & اجبارى نبودن كزارشكرى يايدارى & & \\
\hline$\overline{\frac{1}{3}}$ & $\vdots$ & $\stackrel{<}{\dot{r}}$ & $\frac{2}{i 9}$ & $\vdots$ & $\begin{array}{l}3 \\
3 \\
\frac{3}{2} \\
2\end{array}$ & در معرض ديد دولت قرار كرفتن و فشار دولت & & \\
\hline$\overline{3}$ & $\vdots$ & $\stackrel{a}{\dot{2}}$ & $\frac{2}{9}: 3$ & $\vdots$ & $\begin{array}{l}a \\
\vdots \\
\vdots \\
\vdots\end{array}$ & 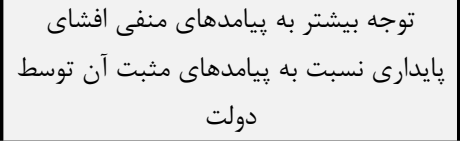 & & \\
\hline$\overline{3}$. & $\vdots$ & $\grave{\vdots}$ & $\frac{2}{9}$ & $\vdots$ & $\begin{array}{l}\dot{\sigma} \\
\dot{\hat{j}} \\
\underline{2}\end{array}$ & |ريامدهاى نامطلوب مربوط به افشاى اخبار بد & & $\frac{9}{2}$ \\
\hline$\frac{\bar{\pi}}{3}$ & $\vdots$ & $\frac{2}{2}$ & $\frac{2}{3}$ & $\vdots$ & $\frac{\bar{亠}}{\underline{a}}$ & فقدان الكو و دشوار بودن اندازهيرى پايدارى & & $\sqrt[5]{3}$ \\
\hline$\overline{\frac{\pi}{3}}$ & $\vdots$ & $\frac{1}{2}$ & $\frac{2}{39}$ & $\vdots$ & $\stackrel{\dot{\dot{s}}}{\dot{3}}$ & سبستمهن بسترهاى لازم جهت افلاعاتى و نيروى انسانى هيحون & & $\begin{array}{c}\frac{3}{3} \\
\frac{3}{3} \\
\vdots \\
\vdots \\
4\end{array}$ \\
\hline$\overline{\frac{\pi}{3}}$ & $\vdots$ & $\frac{\sigma}{2}$ & $\frac{2}{3}$ & $\vdots$ & $\frac{\dot{2}}{2}$ & عدم توانايى شركتها در كردآورى اطلاعات & & \\
\hline$\overline{\frac{\pi}{3}}$ & $\vdots$ & $\frac{2}{2}$ & $\frac{2}{9}$ & $\vdots$ & $\underline{\underline{z}}$ & شوكتهاء استفاده رقبا از اطلاعات محرمانه داد سمهم بازار & & \\
\hline 市. & $\vdots$ & $\underline{z}$ & $\frac{2}{9}$ & $\vdots$ & $\frac{2}{\frac{2}{2}}$ & 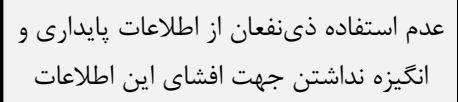 & & \\
\hline$\overline{3}$ & $\vdots$ & $\stackrel{2}{\dot{2}}$ & $\frac{2}{39}$ & $\vdots$ & $\stackrel{\frac{\sigma}{\sigma^{2}}}{\dot{\Sigma}}$ & مبتنى بودن بازار بر شايعات و فضاسازى استفاده به از اطلاعات افشا شده جهت & & \\
\hline
\end{tabular}

منبع: يافتههاى يزوهشكر 
دكتر خدامى يور و همكاران، تدوين و ارزيابى مدل موانع اجرا، افشا و استانداردَذارى يايدارى شركتى در ايران اعَr

همانطور كه در جدول \ مشاهده مىشود، براى كليه شاخصها، سطح معنادارى كمتر از هـ • •

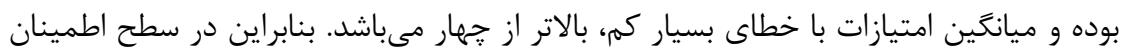

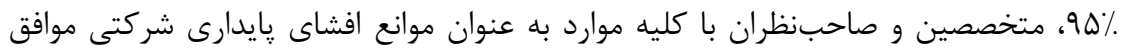

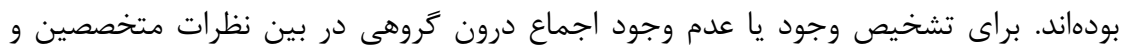

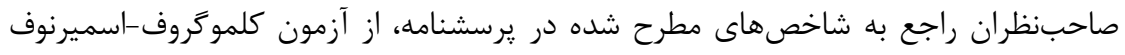

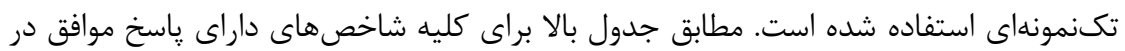

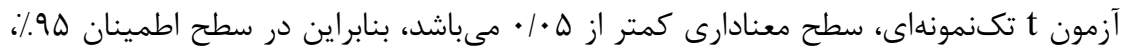

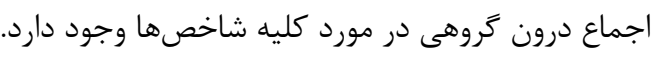

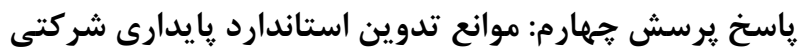

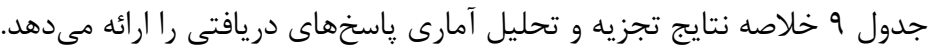

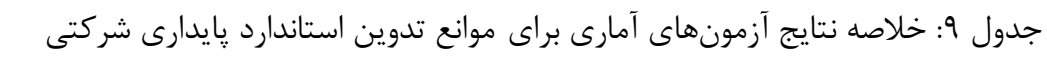

\begin{tabular}{|c|c|c|c|c|c|c|c|c|}
\hline \multirow{2}{*}{\multicolumn{3}{|c|}{ 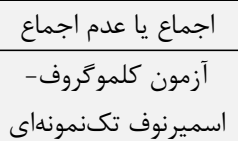 }} & \multirow{2}{*}{\multicolumn{3}{|c|}{ آزمون t تكـنمونهاى يا مخالفت }} & \multirow{3}{*}{\multicolumn{3}{|c|}{ موانع تدوين استاندارد هِايدارى شركتى }} \\
\hline & & & & & & & & \\
\hline 3 & $\begin{array}{l}3 \\
\frac{3}{2} \\
3 \\
3 \\
\frac{3}{9}\end{array}$ & $\frac{3}{3}$ & 3 & $\begin{array}{l}3 \\
-2 \\
3 \\
3 \\
3 \\
y\end{array}$ & $\frac{3}{3}$ & & & \\
\hline$\frac{\pi}{3}$ & $\vdots$ & $\vdots$ & $\frac{2}{3}$ & $\vdots$ & $\underset{a}{a}$ & كَتردى ذىنفعان و خواستههاى & \multirow{4}{*}{$\begin{array}{l}\frac{g}{2} \\
y \\
y\end{array}$} & \multirow{4}{*}{$\begin{array}{c}\frac{2}{12} \\
\frac{1}{2} \\
3 \\
3 \\
3 \\
3 \\
\frac{3}{3} \\
3 \\
\frac{3}{3}\end{array}$} \\
\hline $\begin{array}{l}\overline{3} . \\
\frac{3}{\omega} .\end{array}$ & $\vdots$ & $\begin{array}{l}3 \\
3 \\
3\end{array}$ & $\frac{2}{9}$ & : & $\frac{\sigma}{2}$ & كيفى بودن يايدارى شركتى و دشوار & & \\
\hline$\overline{3}$. & $\vdots$ & $\frac{2}{2}$ & $\frac{2}{9}$ & $\vdots$ & $\frac{z_{a}^{\frac{2}{2}}}{\underline{\underline{a}}}$ & زمانبر بودن فرآيند استانداردكذارى & & \\
\hline$\overline{3}$. & $\vdots$ & $\begin{array}{l}\sigma \\
\dot{2} \\
\dot{2}\end{array}$ & $\frac{2}{9}$ & $\vdots$ & $\frac{\frac{y}{2}}{\frac{\sigma}{\sigma}}$ & هزينهبر بودن فرآيند استانداردكَذارى & & \\
\hline
\end{tabular}

همانطور كه در جدول 9 مشاهده مىشود، براى كليه شاخصها، سطح معنادارى كمتر از ه••• بوده و ميانكين امتيازات با خطاى بسيار كم، بالاتر از جهار مى باشد. بنابراين در سطح

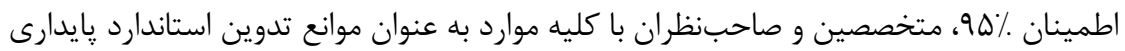
شركتى موافق بودهاند. براى تشخيص وجود يا عدم وجود اجماع درون كروهى در بين نظرات

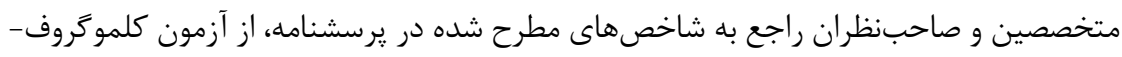

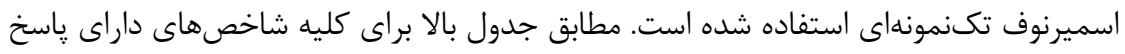


موافق در آزمون t تكنمونهاى، سطح معنادارى كمتر از ه • • • مىباشد، بنابراين در سطح اطمينان

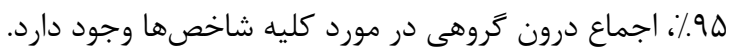

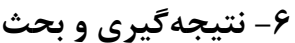

در اين يزوهش سعى شد مدلى متناسب با شرايط اقتصادى، اجتماعى، فرهنكى و سياسى ايران

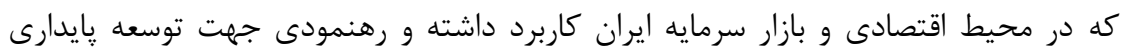

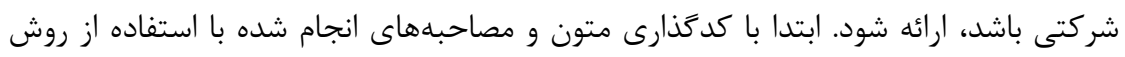

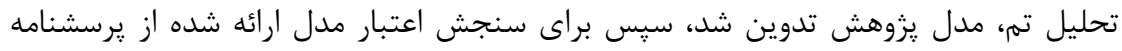

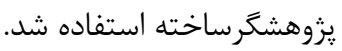

در پاسخ به يرسش اول يزوهش، مدل پايدارى شركتى در ايران داراى سه بُعد شامل، موانع

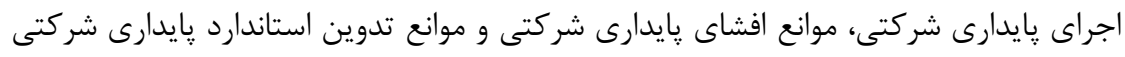

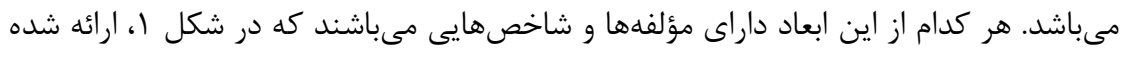

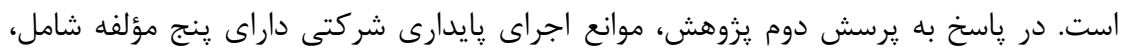

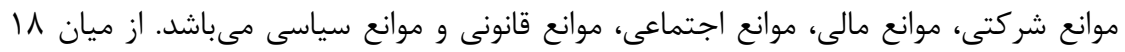

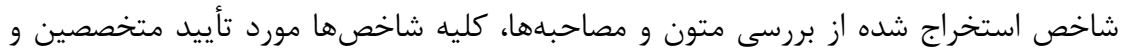

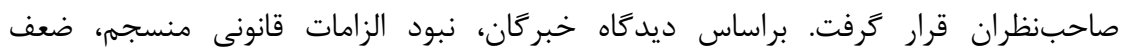

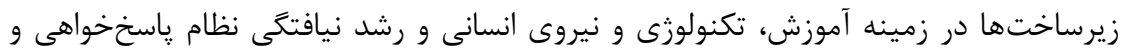

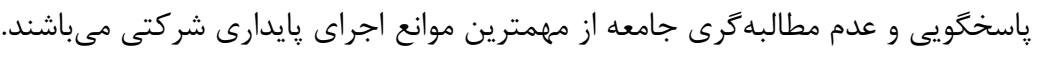

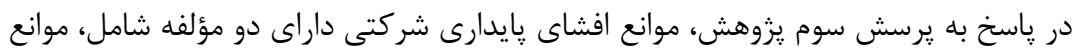

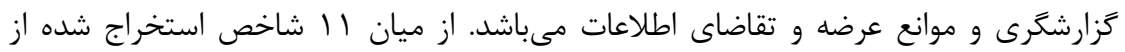

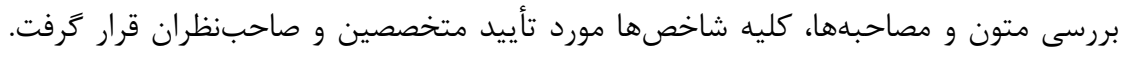

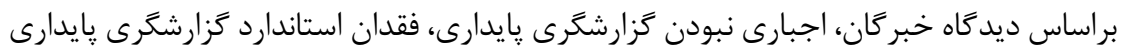

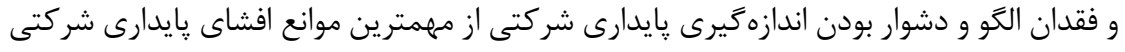

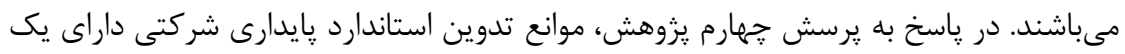

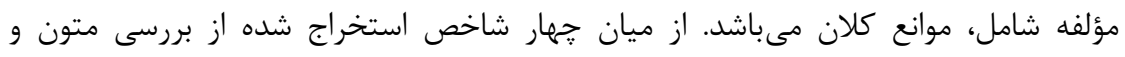

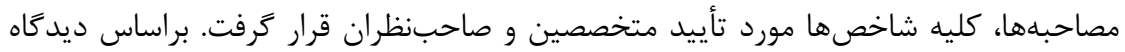

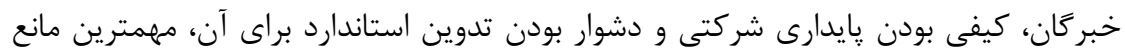

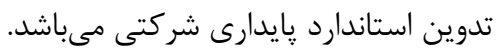

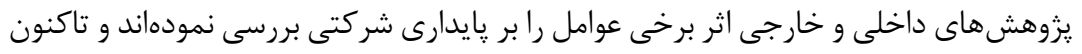

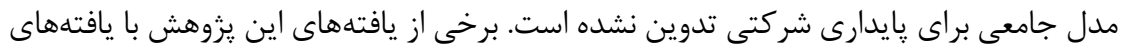


دكتر خدامى يور و همكاران، تدوين و ارزيابى مدل موانع اجرا، افشا و استانداردَذارى يايدارى شركتى در ايران سعץ

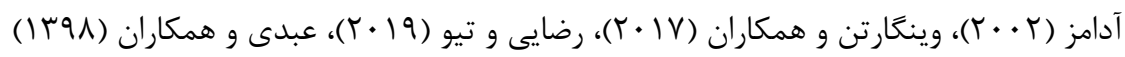

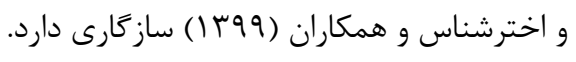

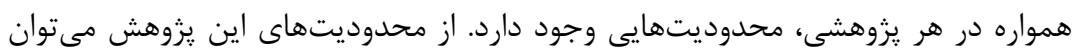

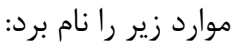

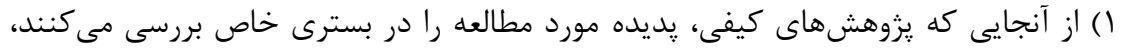

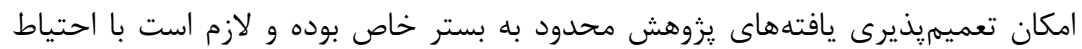

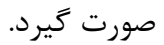

r) با توجه به محدوديتهاى ذاتى يرسشنامه، بايستى يافتهاى آمارى يزوهش با احتياط تعميم

يابد.

با توجه به يافتههاى حاصل از يزوهش، يِيشنهادهايى به شرح زير عنوان مى إنود:

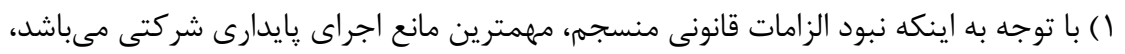

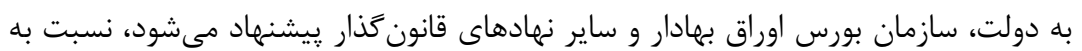

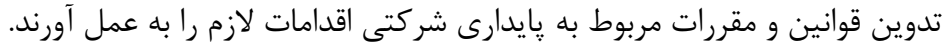

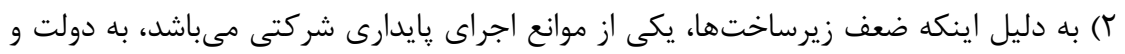

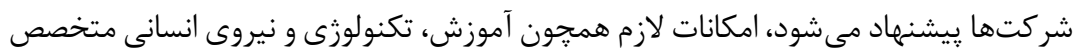
را جهت اجراى پايدارى شركتى فراهم نمايند.

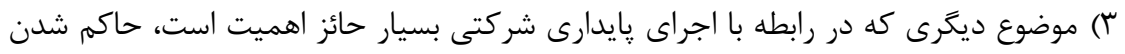

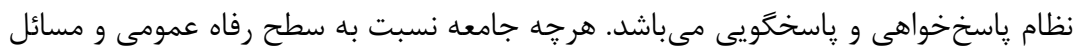
زيستمحيطى حساستر بوده و نسبت به آن دغدغه داشته باشد و از مسئولين ياسخخ هواهى

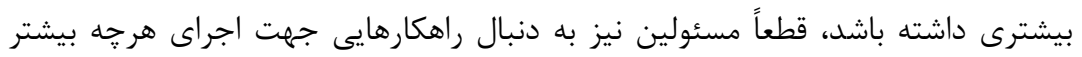

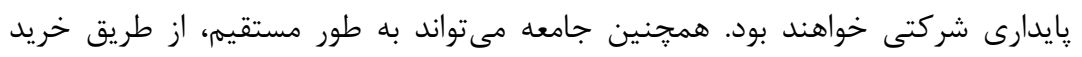

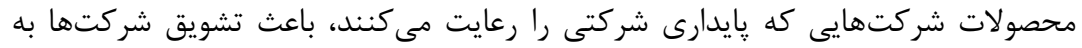

$$
\text { رعايت پايدارى شركتى شود. }
$$

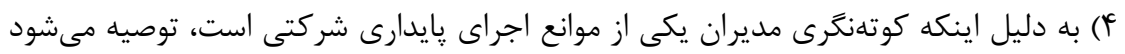

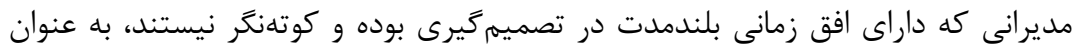

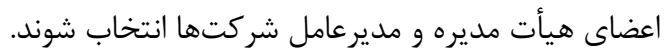

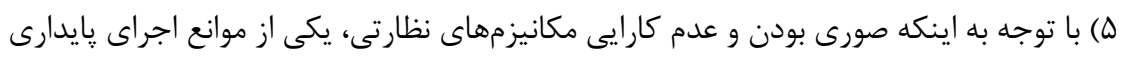

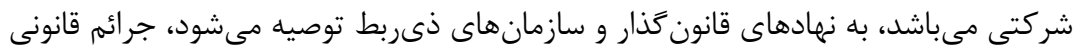

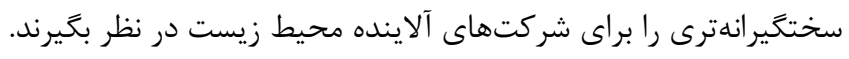


9) با توجه به اينكه سهم عمده دولت در اقتصاد، يكى از موانع اجراى پايدارى شركتى مىباشد،

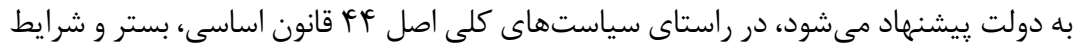

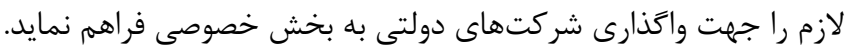
(V

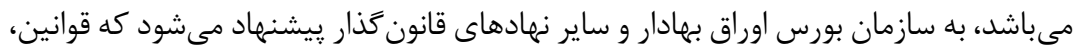

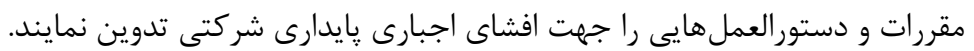

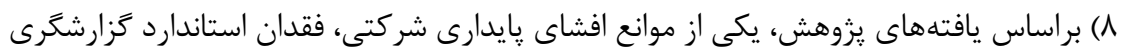

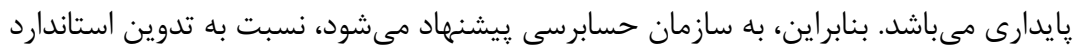

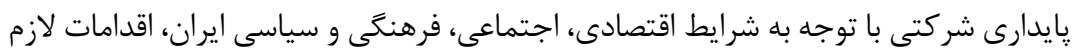

$$
\text { را به عمل آورد. }
$$

ي بيشنهاد براى يزوهشهاى آورد آتى به شرح زير مىباشد:

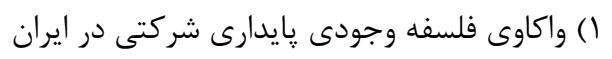

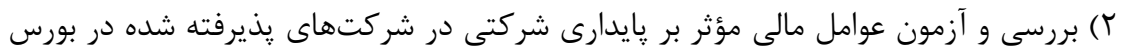

اوراق بهادار تهران

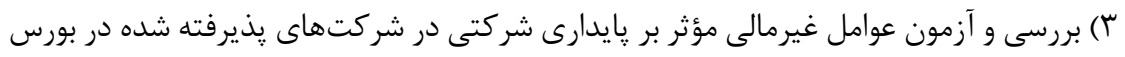
اوراق بهادار تهران

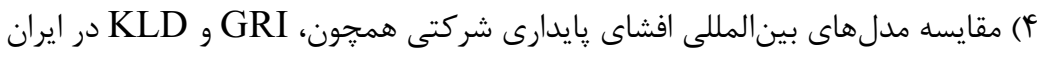

\section{V- Vقدير ، تشكر و ملاحظههاى اخلاقى}

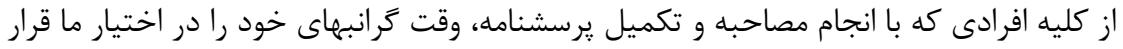
دادهاند، كمال تشكر و قدردانى را داريهم.

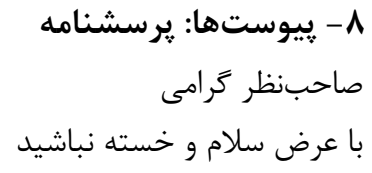
از اينكه زمان خود راصرف مطالعه و تكميل يرسشنامه حاضر مىنماييد، كمال تشكر را داريم.

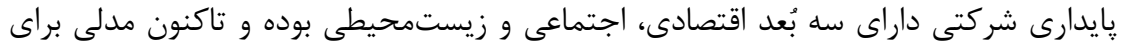

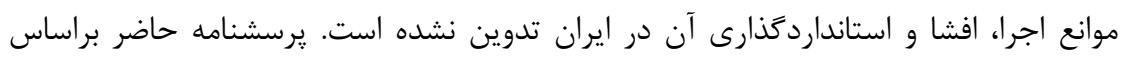

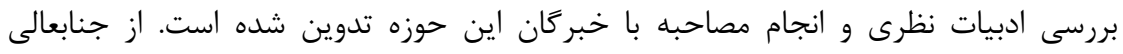




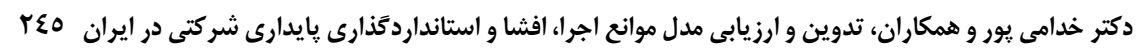

درخواست مى كردد كه مصداق هر يك از عوامل معرفى شده را به عنوان بخشى از مدل تدوين شده مورد ارزيابى قرار دهيد.

ا- به نظر شما موارد زير تا جه اندازه مى تواند مانع اجراى بايدارى شركتى در ايران باشد:

\begin{tabular}{|c|c|c|c|c|c|c|c|c|}
\hline hy: & $v_{k}$ & "3. & a & 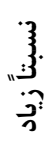 & $?$ & ?at & 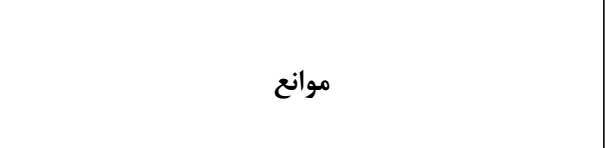 & $\hat{\jmath}$ \\
\hline$\square$ & $\square$ & $\square$ & $\square$ & $\square$ & $\square$ & $\square$ & تأكيد مجمع عمومى صاحبان سهام بر سودآورى & 1 \\
\hline$\square$ & $\square$ & $\square$ & $\square$ & $\square$ & $\square$ & $\square$ & ارزيابى صرف عملكرد مالى مديران و نظام پاداشدهى بر & $r$ \\
\hline$\square$ & $\square$ & $\square$ & $\square$ & $\square$ & $\square$ & $\square$ & كوتهنكَى مديران & $r$ \\
\hline$\square$ & $\square$ & $\square$ & $\square$ & $\square$ & $\square$ & $\square$ & ضعف زيرساختها در زمينه آموزش، تكنولوزى و نيروى & $r$ \\
\hline$\square$ & $\square$ & $\square$ & $\square$ & $\square$ & $\square$ & $\square$ & 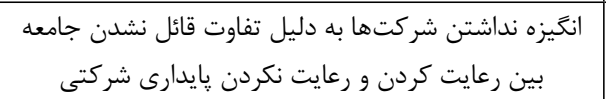 & $\Delta$ \\
\hline$\square$ & $\square$ & $\square$ & $\square$ & $\square$ & $\square$ & $\square$ & اعتقاد نداشتن شركتها به اثرات منفى فعاليتهاى آنها بر & 4 \\
\hline$\square$ & $\square$ & $\square$ & $\square$ & $\square$ & $\square$ & $\square$ & مطرح نبودن رقابت در سطح ملى و بينالمللى & $\mathrm{V}$ \\
\hline$\square$ & $\square$ & $\square$ & $\square$ & $\square$ & $\square$ & $\square$ & وضعيت مالى نامناسب شركتها & $\wedge$ \\
\hline$\square$ & $\square$ & $\square$ & $\square$ & $\square$ & $\square$ & $\square$ & بالا بودن هزينههاى اجرا & 9 \\
\hline$\square$ & $\square$ & $\square$ & $\square$ & $\square$ & $\square$ & $\square$ & كم توجهى به مسائل زيستمحيطى و اجتماعى در جامعه & $1 \cdot$ \\
\hline$\square$ & $\square$ & $\square$ & $\square$ & $\square$ & $\square$ & $\square$ & عدم آكَاهى ذىنفعان از پايدارى شركتى و مزاياى رقابتى آن & 11 \\
\hline$\square$ & $\square$ & $\square$ & $\square$ & $\square$ & $\square$ & $\square$ & توجه جامعه به منافع فردى كوتاه مدت & IT \\
\hline$\square$ & $\square$ & $\square$ & $\square$ & $\square$ & $\square$ & $\square$ & 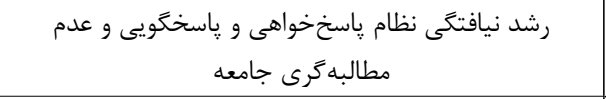 & $\pi$ \\
\hline$\square$ & $\square$ & $\square$ & $\square$ & $\square$ & $\square$ & $\square$ & نبود الزامات قانونى منسجم & if \\
\hline$\square$ & $\square$ & $\square$ & $\square$ & $\square$ & $\square$ & $\square$ & عدم وجود مكانيزمهاى نظارتى بر رفتار شركتها & 10 \\
\hline$\square$ & $\square$ & $\square$ & $\square$ & $\square$ & $\square$ & $\square$ & صورى بودن و عدم كارايى مكانيزمهاى نظارتى & 19 \\
\hline$\square$ & $\square$ & $\square$ & $\square$ & $\square$ & $\square$ & $\square$ & حمايت دولت از صنايع انحصارى & IV \\
\hline$\square$ & $\square$ & $\square$ & $\square$ & $\square$ & $\square$ & $\square$ & سهمم عمده دولت در اقتصاد & 11 \\
\hline
\end{tabular}




\begin{tabular}{|c|c|c|c|c|c|c|c|c|}
\hline $\begin{array}{l}3: \\
3 \\
z\end{array}$ & $\eta_{2}$ & .3. & $\begin{array}{l}\mathfrak{3} \\
3 \\
\mathfrak{3}\end{array}$ & $\begin{array}{c}3 \\
3 \\
3 \\
3 \\
3\end{array}$ & ?’ & $\begin{array}{l}3 \\
3 \\
3 \\
3\end{array}$ & 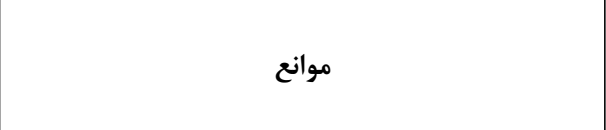 & $\hat{\mathfrak{s}}$ \\
\hline$\square$ & $\square$ & $\square$ & $\square$ & $\square$ & $\square$ & $\square$ & فقدان استاندارد كَارشكَى يايدارى & 1 \\
\hline$\square$ & $\square$ & $\square$ & $\square$ & $\square$ & $\square$ & $\square$ & اجبارى نبودن گَزارشخرى يايدارى & r \\
\hline$\square$ & $\square$ & $\square$ & $\square$ & $\square$ & $\square$ & $\square$ & در معرض ديد دولت قرار كرفتن و فشار دولت بر شركتها و & $r$ \\
\hline$\square$ & $\square$ & $\square$ & $\square$ & $\square$ & $\square$ & $\square$ & 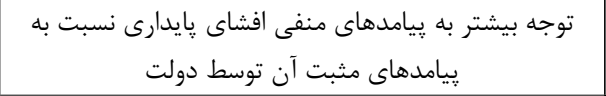 & f \\
\hline$\square$ & $\square$ & $\square$ & $\square$ & $\square$ & $\square$ & $\square$ & ييامدهاى نامطلوب مربوط به افشاى اخبار بد & $\Delta$ \\
\hline$\square$ & $\square$ & $\square$ & $\square$ & $\square$ & $\square$ & $\square$ & فقدان الكَو و دشوار بودن اندازهيرى يايدارى شركتى & 9 \\
\hline$\square$ & $\square$ & $\square$ & $\square$ & $\square$ & $\square$ & $\square$ & نبود بسترهاى لازم جهت افشا همجون سيستمهاى اطلاعاتى & 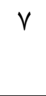 \\
\hline$\square$ & $\square$ & $\square$ & $\square$ & $\square$ & $\square$ & $\square$ & عدم توانايى شركتها در گردآورى اطلاعات & $\wedge$ \\
\hline$\square$ & $\square$ & $\square$ & $\square$ & $\square$ & $\square$ & $\square$ & - سوء استفاده رقبا از اطلاعات محرمانه شركتها و از دست & 9 \\
\hline$\square$ & $\square$ & $\square$ & $\square$ & $\square$ & $\square$ & $\square$ & عدم استفاده ذى نفعان از اطلاعات يايدارى و انخيزه نداشتن & 1 . \\
\hline$\square$ & $\square$ & $\square$ & $\square$ & $\square$ & $\square$ & $\square$ & 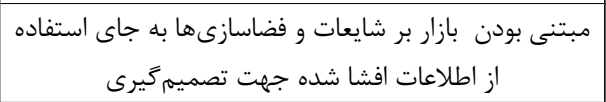 & 11 \\
\hline
\end{tabular}

ب- به نظر شما موارد زير تا جه اندازه مىتواند مانع تدوين استاندارد يايدارى شركتى در ايران باشد:

\begin{tabular}{|c|c|c|c|c|c|c|c|c|}
\hline $\begin{array}{l}3 \\
3 \\
z_{2}\end{array}$ & $z_{2}$ & .3. & $\underset{3}{3}$ & 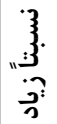 & ?) & $\begin{array}{l}3 \\
3 \\
3 \\
3\end{array}$ & 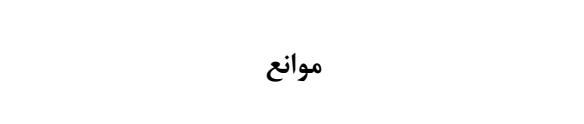 & $\hat{\mathfrak{s}}$ \\
\hline$\square$ & $\square$ & $\square$ & $\square$ & $\square$ & $\square$ & $\square$ & حستردىى ذىنفعان و خواستههاى متفاوت آنان & 1 \\
\hline$\square$ & $\square$ & $\square$ & $\square$ & $\square$ & $\square$ & $\square$ & كيفى بودن پايدارى شركتى و دشوار بودن تدوين استاندارد & r \\
\hline$\square$ & $\square$ & $\square$ & $\square$ & $\square$ & $\square$ & $\square$ & زمانبر بودن فرآيند استانداردكذارى & r \\
\hline$\square$ & $\square$ & $\square$ & $\square$ & $\square$ & $\square$ & $\square$ & هزينهبر بودن فرآيند استانداردَذارى & r \\
\hline
\end{tabular}




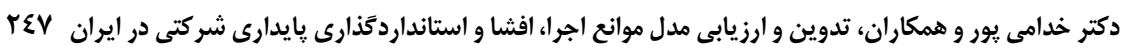

فهرست منابع

اخترشناس، داريوش؛ خدامى يور، احمد؛ يورحيدرى، اميد. (99 (1)، تدوين مدل عوامل مؤثر بر

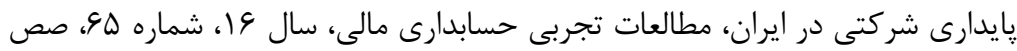

$. r \cdot 1-1 V \Delta$

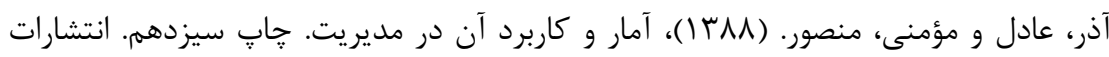

سمت.

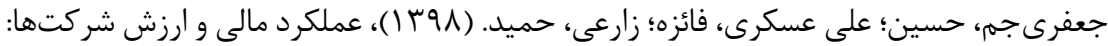

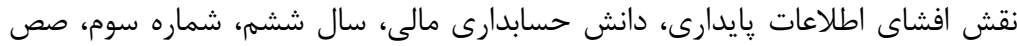

TFY-TID

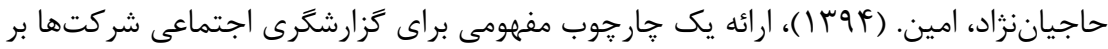
مبناى جار جوب مفهومى حسابدارى در ايران، ياياننامه دوره دكترى حسابدارى، دانشگاه

$$
\text { شهيد باهنر كرمان. }
$$

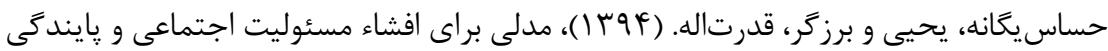
شركتها و وضعيت موجود آن در شركتهاى يذيرفته شده در بورس اوراق بهادار ايران،

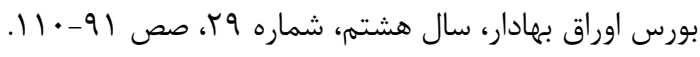

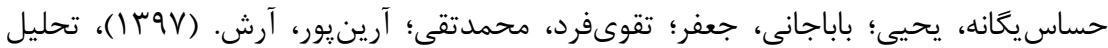

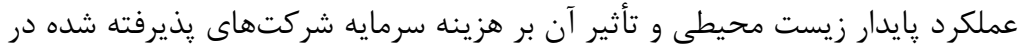
بورس اوراق بهادار تهران، حسابدارى ارزشى و رفتارى، سال سوم، شماره ينجم، صص له

rq-1

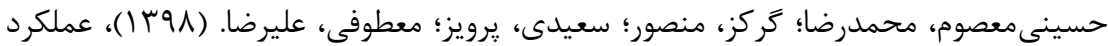

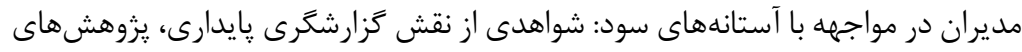

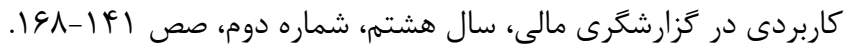

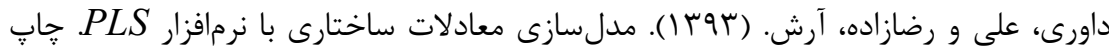
دوم. انتشارات جهاد دانشعاهى.

ديانتى ديلمى، زهرا. (Vqr)). روش تحقيق در حسابدارى: با تاكيد بر تحقيقات كيفى (ويزه مقطع كارشناسى). جاب اول. انتشارات عدالت نوين.

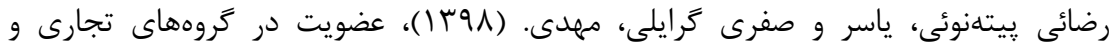

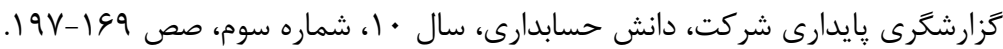




$$
\begin{aligned}
& \text { دوفصلنامه حسابدارى ارزشى و رفتارى، سال ششم، شماره يازدهم، بهار و تابستان +.ع| } \\
& \text { عبدالهزاده، حسن و امين، وحيد. (99 (1)، تأثير نظريه رفتار برنامهريزى شده، تعهد اخلاقى و }
\end{aligned}
$$

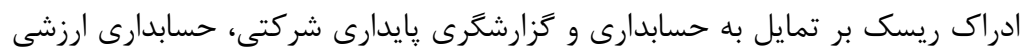

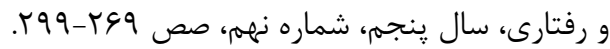

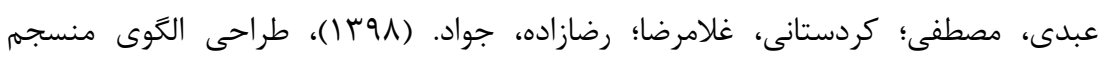

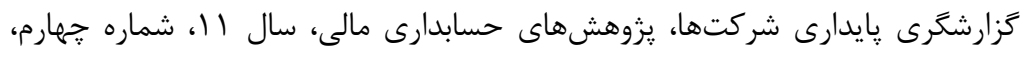

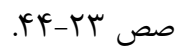

$$
\begin{aligned}
& \text { فخارى، حسين؛ ملكيان، اسفنديار؛ جفائىرهنى، منير. (9 9 |)، تبيين و رتبابندى مؤلفهها و }
\end{aligned}
$$

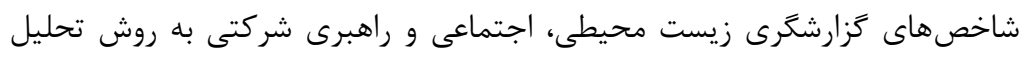

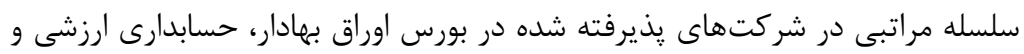

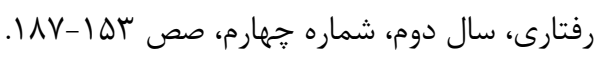

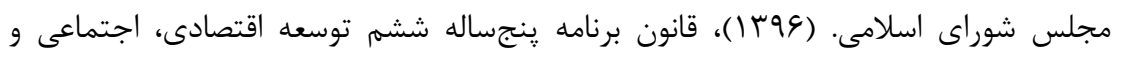

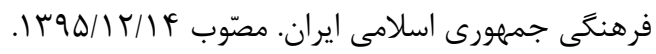

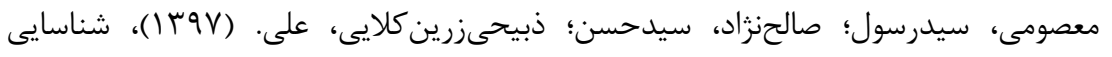

$$
\begin{aligned}
& \text { متغيرهاى مؤثر بر ميزان گزارشخرى يايدارى شركتهاى }
\end{aligned}
$$

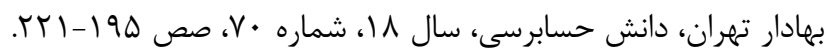

Aksoy, M., M. K. Yilmaz, E. Tatoglu, and M. Basar. 2020. Antecedents of corporate sustainability performance in Turkey: The effects of ownership structure and board attributes on non-financial companies. Journal of Cleaner Production 276: 1-11.

Bona-Sanchez, C., J. Perez-Aleman, and D. J. Santana-Martin. 2017. Sustainability disclosure, dominant owners and earnings informativeness. Research in International Business and Finance 39 (1): 625-639.

Braun, V., and V. Clarke. 2006. Using thematic analysis in psychology. Qualitative research in psychology 3 (2): 77-101.

Bremser, W. G. 2014. A Growing Interest in Sustainability Paving the Way for the Next Generation of CPAs. The CPA Journal: 15-17.

Correa-Garcia, J. A., M. A. Garcia-Benau, and E. Garcia-Meca. 2020. Corporate governance and its implications for sustainability reporting quality in Latin American business groups. Journal of Cleaner Production. 260: 1-12.

Farneti, F., and J. Guthrie. 2009. Sustainability reporting by Australian public sector organizations: Why they report. Accounting Forum 33 (2): 89-98.

Gallego-Alvareza, I., and E. Ortas. 2016. Corporate environmental sustainability reporting in the context of national cultures: A quantile regression approach. International Business Review 26 (2): 337-353.

Garcia-Sanchez, I. M., O. Suarez-Fernandez, and J. Martinez-Ferrero. 2019. Female directors and impression management in sustainability reporting. International Business Review 28 (2): 359-374. 
دكتر خدامى يور و همكاران، تدوين و ارزيابى مدل موانع اجرا، افشا و استانداردَذارى يايدارى شركتى در ايران وعج

Hopkins, M. 2004. Corporate social responsibility: an issue paper. Working Paper, 27, International Labour Organisation. Geneva.

Jesica, F. 2011. Sustainability performance management. Accenture and Chartered Institute of Management Accountants.

KPMG. 2011. KPMG International Survey of Corporate Responsibility Reporting.

Kraten, M. 2014. Sustainability the Accounting Perspective. The CPA Journal: 1114.

Lang, M., K. V. Lins, and M. Maffett. 2012. Transparency, Liquidity, and Valuation: International Evidence on When Transparency Matters Most. Journal of Accounting Research 50 (3): 729-774.

Mahmood, Z., R. Kouser, W. Ali, Z. Ahmad, and T. Salman. 2018. Does Corporate Governance Affect Sustainability Disclosure? A Mixed Methods Study. Sustainability 10 (1): 207-226.

McGuire, J. B. 1963. Business and Society. McGraw-Hill. New York.

$\mathrm{Ng}$, A. C., and Z. Rezaee. 2015. Business sustainability performance and cost of equity capital. Journal of Corporate Finance 34: 128-149.

Parmar, B. L., R. E. Freeman, J. S. Harrison, A. C. Wicks, S. de Colle, and L. Purnell. 2010. Stakeholder Theory: The State of the Art. Cambridge University Press. New York.

Ray, S., and B. R. Chaudhuri. 2018. Business Group Affiliation and Corporate Sustainability Strategies of Firms: An Investigation of Firms in India. Journal of Business Ethics 153 (4): 955-976.

Rezaee, Z., L. Tuo. 2019. Are the Quantity and Quality of Sustainability Disclosures Associated with the Innate and Discretionary Earnings Quality? Journal of Business Ethics 155 (8): 763-786.

Sneirson, J. F. 2009. Green is good: Sustainability, Profitability, and a New Paradigm for Corporate Governance. Iowa Law Review 94 (3): 987-1022.

Wiengarten, F., C. K. Y. Lo, and J. Y. K. Lam. 2017. How does Sustainability Leadership Affect Firm Performance? The Choices Associated with Appointing a Chief Officer of Corporate Social Responsibility. Journal of Business Ethics 140 (3): 477-493.

Zhang, J. 2017. Users' perceptions of the drivers for corporate sustainability disclosures made by Chinese listed companies. Theses: Doctorates and Masters, Edith Cowan University. 